\title{
Effect of pasteurization and fat, protein, casein to serum protein ratio, and milk temperature on milk beverage color and viscosity
}

\author{
Ni Cheng, ${ }^{1}$ David M. Barbano, ${ }^{2 *}$ and Mary Anne Drake ${ }^{1}$ \\ ${ }^{1}$ Southeast Dairy Foods Research Center, North Carolina State University, Raleigh 27695 \\ ${ }^{2}$ Northeast Dairy Foods Research Center, Department of Food Science, Cornell University, Ithaca, NY 14853
}

\section{ABSTRACT}

Our goal was to determine the effect of pasteurization-homogenization, fat and protein concentration, proportion of milk protein that is casein and serum protein, and temperature on sensory and instrumental measures of viscosity and color of milk-based beverages. A second goal was to use instrumental measures of whiteness and yellowness to predict sensory measures of whiteness and yellowness. A complete balanced 3 factor (fat, true protein, and casein as a percentage of true protein) design was applied with 3 levels of fat $(0.2,1.0$ and $2.0 \%), 4$ levels of true protein $(3.00,3.67$, 4.34 , and $5.00 \%$ ) within each fat level, and 5 levels of casein as a percentage of true protein $(\mathrm{CN} \% \mathrm{TP} ; 5,25$, 50,75 , and $80 \%$ ) within each protein level for beverage formulation. Instrumental color and viscosity, and visual sensory color analyses were done on each beverage formulation. For unpasteurized beverages across 3 fat levels $(0.2,1$, and $2 \%$ ), changes in CN\% TP had the largest effect on L values, sensory whiteness, opacity, color intensity, and yellowness, whereas changes in fat concentration had a stronger influence on $\mathrm{a}$ and $\mathrm{b}^{*}$ values. Increasing CN\% TP from 5 to $80 \%$ increased $\mathrm{L}$ values, sensory whiteness, and opacity, and decreased sensory color intensity and yellowness. The a and $b^{*}$ values increased with increasing fat concentration. For unpasteurized milk protein beverages within each fat level, variation in CN\% TP dominated the changes in L values, sensory whiteness, and opacity, and decreased a and $b^{*}$ values, sensory color intensity, and yellowness. The effect of heat (pasteurization and homogenization) and its interaction terms had the second largest effect on color of milk protein beverages with respect to instrumental color data and sensory appearance attributes. Heat increased L values, sensory whiteness, and opacity, and decreased $\mathrm{a}$ and $\mathrm{b}^{*}$ values, sensory color intensity, and yellowness. Increases in tempera-

Received September 22, 2018.

Accepted October 18, 2018.

*Corresponding author: dmb37@cornell.edu ture decreased instrumental viscosity and changes in protein concentration and CN\% TP had a greater effect on instrument viscosity data within each temperature $\left(4,20\right.$, and $\left.50^{\circ} \mathrm{C}\right)$ than fat. Sensory perception of yellowness was not highly correlated with $\mathrm{b}^{*}$ values. Multiple linear regressions of $\mathrm{L}, \mathrm{a}$, and $\mathrm{b}^{*}$ values produced more robust predictions for both sensory whiteness and yellowness than simple linear regression with $\mathrm{L}$ and $b^{*}$ values alone, and may be a useful instrumental approach for quality control of sensory whiteness and yellowness of milk protein beverages.

Key words: casein as a percent of true protein, protein beverage, sensory whiteness and yellowness

\section{INTRODUCTION}

Hunter (L, a, and b) and International Commission on Illumination (CIE) $\mathrm{L}^{*}, \mathrm{a}^{*}$, and $\mathrm{b}^{*}$ color measurement systems are widely used in color measurement of dairy and dairy products. The intent of development of these 2 color measurement systems was to generate a uniform color space for color measurement. The Hunter ( $\mathrm{L}, \mathrm{a}, \mathrm{b})$ system is more sensitive in measuring blueness, whereas the CIE $\left(\mathrm{L}^{*}, \mathrm{a}^{*}, \mathrm{~b}^{*}\right)$ system is more sensitive in measuring yellowness and dark colors (CIE, 1978; Hunter and Harold, 1987; Hunter Associates Laboratory, 2012). Cheng et al. (2018) recently applied both systems for color measurement of milk beverages and concluded that for best sensitivity in instrumental color analysis of dairy beverages, Hunter L values for whiteness and CIE b* values for yellowness were recommended as the most sensitive whereas there was little difference between the selection of Hunter a and CIE $a^{*}$ values at a viewer angle of 10 degree using illuminant A. Measurement temperature, viewer angle, and illuminant also need to be reported for reproducibility of instrumental color measurements.

The relationship between visual instrumental data and sensory attributes of dairy products have been investigated by several researchers. Guinard and Mazzucchelli (1999) found a high correlation $(\mathrm{R}=0.98)$ between instrumental color lightness ( $\mathrm{L}$ values) and 
sensory darkness in 9 milk chocolates with varying sugar and cocoa butter levels. Tárrega and Costell (2007) observed strong correlations between instrumental color measurement (CIE color system, at 10 degree viewer angle) and sensory ranking of yellow color of 7 dairy desserts. Hetherington and MacDougall (1991) used principal component analysis (PCA) to understand the inter-relationship between visual instrumental (CIE color system, at 10 degree viewer angle) data and sensory data for whole milk, and they also built regression models to predict sensory data using multiple visual instrumental variables. The multiple correlation coefficient they reported for color and lightness of whole milk were both 0.80 (Hetherington and MacDougall, 1991). It is possible to use the visual instrumental data to generate a prediction model for sensory attributes. Sensory color attribute prediction from instrumental data could help dairy product manufactures to better control the quality of products in real time to meet consumers' expectations for color of milk protein beverages.

Several studies have reported milk color and its effects on perception and preferences for milk and milk protein beverages. Pangborn et al. (1985) pointed out that visual cues were important for milk differentiation based on fat level. Phillips et al. (1995a) reported that milk appearance also influenced the perceived mouthfeel of low-fat milk. Milk appearance was correlated with color perception of low fat milk when increasing fat from 0.06 to $0.2 \%$, and addition of titanium dioxide also increased the sensory scores for low fat milk appearance (Phillips et al., 1995a; Phillips and Barbano, 1997). Increases in true protein (TP) level (Quiñones et al., 1997, 1998) and casein as a percentage of TP (Misawa et al., 2016) increased sensory whiteness of low-fat milks. McCarthy et al. (2017) conducted consumer interviews with consumers and concluded that better color or whiteness was one reason that milk drinkers, regardless of what type of milk they regularly consumed, preferred higher fat level milks when the fat content was not disclosed. Currently, consumers are interested in high protein food products and high protein milk-based beverages deliver high quality protein in a ready to consume form that needs to look and taste great. Today, commercial membrane filtration technology offers milk processing approaches to concentrate and fractionate milk proteins for use as fresh liquid ingredients in high protein milkbased beverages. Different combinations of milk protein concentration and protein types (native casein micelles versus milk serum proteins) can produce different flavor and functionalities in high protein beverages. Data are needed to understand the effect of these ingredients on high protein dairy beverage flavor and functionality. One objective of our work was to determine the effect of pasteurization-homogenization, fat and protein concentration, proportion of milk protein that is casein and serum protein, and sample temperature on sensory and instrumental measures of viscosity and whiteness, red/green, and blue/yellow color of milk-based beverages. A second objective was to use instrumental measures of whiteness and yellowness to predict sensory measures of whiteness and yellowness in unpasteurized milk protein beverages.

\section{MATERIALS AND METHODS}

\section{Experimental Design}

Beverage formulations were based on a complete balanced 3-factor (fat, TP, and casein as a percentage of $\mathrm{TP})$ design with 3 fat levels $(0.2,1.0$, and $2.0 \%), 4 \mathrm{TP}$ levels $(3.00,3.67,4.34$, and $5.00 \%)$ within each fat level, and 5 casein as a percentage of true protein $(\mathbf{C N \%} \mathbf{T P})$ levels $(5,25,50,75$, and $80 \%)$ within each protein level (for a total of 60 formulations within each replicate; Table 1). The formulation, sensory, and analytical work was done in $1 \mathrm{wk}$ for each fat level and there was a replication of the formulation, processing, and analysis for all the treatments within each fat level in a second week, for a total of 6 wk of processing. Instrumental measures of $\mathrm{L}, \mathrm{a}$, and $\mathrm{b}^{*}$ values, instrumental viscosity, and visual sensory analysis of color were done on each unpasteurized and pasteurized/homogenized beverage formulation. The effect of unpasteurized beverage composition on instrumental and sensory measures of appearance was analyzed separately and then together with the same formulation after pasteurization/homogenization to determine the effect of processing on appearance over the range of fat, protein, and $\mathrm{CN} \% \mathrm{TP}$ in the group of formulations.

\section{Milk-Based Ingredients and Beverages Processing}

The ingredients used for beverage formulation and pasteurization-homogenization processing were as described by Cheng et al. (2018). The relative weight percentage of usage of each ingredient in each formulation is listed in Table 1.

Milk Micellar Casein Concentrate. Liquid milk micellar casein concentrate (MCC) was made the day before beverage formulation as described by Cheng et al. (2018). A 3-stage, $3 \times$ microfiltration (MF) process described by Zulewska and Barbano (2014) was used to produce a $95 \%$ serum protein removed MCC with true protein concentration between 8.4 to $8.6 \%$ (Cheng et al., 2018) using an MF system (Tetra Alcross MFS7, TetraPak Filtration Systems) equipped with $0.1-\mu \mathrm{m}$ nominal pore diameter graded permeability ceramic Membralox (model EP1940GL0.1u, AGP1020, alumi- 
Table 1. Formulation design and relative weight percentage use of ingredients for $0.2,1.0$, and $2.0 \%$ fat level with a range of casein as a percentage of true protein $(\mathrm{CN} \% \mathrm{TP})$ of $5,25,50,75$, and $80 \%$ and true protein $(\mathrm{TP})$ levels of $3.00,3.67,4.34$, and $5.00 \%$ within each fat level $^{1}$

\begin{tabular}{|c|c|c|c|c|c|c|c|c|c|}
\hline Fat $(\%)$ & \multicolumn{2}{|c|}{ Protein } & \multicolumn{2}{|c|}{ Formulation code } & MCC & SPI & Lactose & $\begin{array}{l}\text { Heavy } \\
\text { cream }\end{array}$ & $\begin{array}{c}\text { DI } \\
\text { water }\end{array}$ \\
\hline & 50 & 3.00 & R3 & P3 & 18.95 & 5.88 & 4.72 & 0.36 & 70.09 \\
\hline & 75 & 3.00 & $\mathrm{R} 4$ & $\mathrm{P} 4$ & 28.89 & 2.38 & 4.67 & 0.30 & 63.75 \\
\hline & 80 & 3.00 & R5 & P5 & 30.88 & 1.68 & 4.66 & 0.29 & 62.48 \\
\hline & 50 & 3.67 & $\mathrm{R} 8$ & P8 & 23.20 & 7.19 & 4.69 & 0.34 & 64.58 \\
\hline & 75 & 3.67 & R9 & P9 & 35.37 & 2.91 & 4.62 & 0.26 & 56.84 \\
\hline & 80 & 3.67 & R10 & P10 & 37.80 & 2.06 & 4.61 & 0.24 & 55.29 \\
\hline & 5 & 4.34 & R11 & P11 & 1.54 & 17.62 & 4.79 & 0.47 & 75.58 \\
\hline & 25 & 4.34 & R12 & $\mathrm{P} 12$ & 13.05 & 13.57 & 4.73 & 0.40 & 68.25 \\
\hline & 50 & 4.34 & R13 & $\mathrm{P} 13$ & 27.45 & 8.51 & 4.65 & 0.31 & 59.09 \\
\hline & 75 & 4.34 & R14 & $\mathrm{P} 14$ & 41.84 & 3.45 & 4.57 & 0.22 & 49.92 \\
\hline & 80 & 5.00 & $\mathrm{R} 20$ & $\mathrm{P} 20$ & 51.53 & 2.80 & 4.51 & 0.16 & 41.00 \\
\hline \multirow[t]{13}{*}{1.0} & 5 & 3.00 & R21 & P21 & 0.69 & 12.17 & 4.77 & 2.44 & 79.94 \\
\hline & 25 & 3.00 & $\mathrm{R} 22$ & P22 & 8.65 & 9.36 & 4.72 & 2.39 & 74.87 \\
\hline & 50 & 3.00 & $\mathrm{R} 23$ & P23 & 18.60 & 5.87 & 4.67 & 2.32 & 68.54 \\
\hline & 75 & 3.00 & R24 & P24 & 28.55 & 2.37 & 4.62 & 2.26 & 62.21 \\
\hline & 80 & 3.00 & $\mathrm{R} 25$ & P25 & 30.54 & 1.67 & 4.61 & 2.25 & 60.94 \\
\hline & 5 & 3.67 & R26 & P26 & 0.94 & 14.89 & 4.75 & 2.43 & 76.99 \\
\hline & 25 & 3.67 & $\mathrm{R} 27$ & $\mathrm{P} 27$ & 10.68 & 11.46 & 4.70 & 2.37 & 70.79 \\
\hline & 50 & 3.67 & $\mathrm{R} 28$ & P28 & 22.85 & 7.18 & 4.63 & 2.30 & 63.04 \\
\hline & 75 & 3.67 & R29 & $\mathrm{P} 29$ & 35.02 & 2.90 & 4.57 & 2.22 & 55.29 \\
\hline & 80 & 3.67 & R30 & P30 & 37.46 & 2.04 & 4.56 & 2.20 & 53.74 \\
\hline & 5 & 4.34 & R31 & P31 & 1.19 & 17.61 & 4.73 & 2.43 & 74.03 \\
\hline & 25 & 4.34 & R32 & P32 & 12.71 & 13.56 & 4.67 & 2.36 & 66.70 \\
\hline & 50 & 4.34 & R33 & P33 & 27.10 & 8.49 & 4.59 & 2.27 & 57.54 \\
\hline \multirow{18}{*}{2.0} & 50 & 3.00 & $\mathrm{R} 43$ & $\mathrm{P} 43$ & 18.11 & 5.84 & 4.63 & 4.78 & 66.64 \\
\hline & 75 & 3.00 & R44 & P44 & 28.06 & 2.34 & 4.58 & 4.72 & 60.30 \\
\hline & 80 & 3.00 & $\mathrm{R} 45$ & P45 & 30.05 & 1.64 & 4.56 & 4.70 & 59.04 \\
\hline & 5 & 3.67 & $\mathrm{R} 46$ & $\mathrm{P} 46$ & 0.45 & 14.86 & 4.71 & 4.89 & 75.09 \\
\hline & 25 & 3.67 & R47 & $\mathrm{P} 47$ & 10.19 & 11.44 & 4.65 & 4.83 & 68.89 \\
\hline & 50 & 3.67 & R48 & P48 & 22.36 & 7.16 & 4.59 & 4.75 & 61.14 \\
\hline & 75 & 3.67 & R49 & P49 & 34.53 & 2.88 & 4.53 & 4.67 & 53.39 \\
\hline & 80 & 3.67 & $\mathrm{R} 50$ & $\mathrm{P} 50$ & 36.97 & 2.02 & 4.51 & 4.66 & 51.84 \\
\hline & 5 & 4.34 & R51 & P51 & 0.70 & 17.59 & 4.69 & 4.89 & 72.13 \\
\hline & 25 & 4.34 & R52 & P52 & 12.22 & 13.53 & 4.63 & 4.82 & 64.80 \\
\hline & 50 & 4.34 & R53 & P53 & 26.61 & 8.47 & 4.55 & 4.72 & 55.64 \\
\hline & 75 & 4.34 & R54 & P54 & 41.01 & 3.41 & 4.48 & 4.63 & 46.47 \\
\hline & 80 & 4.34 & $\mathrm{R} 55$ & P55 & 43.89 & 2.40 & 4.46 & 4.61 & 44.64 \\
\hline & 5 & 5.00 & R56 & P56 & 0.95 & 20.27 & 4.67 & 4.89 & 69.22 \\
\hline & 25 & 5.00 & R57 & $\mathrm{P} 57$ & 14.22 & 15.60 & 4.60 & 4.80 & 60.78 \\
\hline & 50 & 5.00 & R58 & P58 & 30.80 & 9.77 & 4.51 & 4.70 & 50.22 \\
\hline & 75 & 5.00 & R59 & P59 & 47.38 & 3.93 & 4.43 & 4.59 & 39.66 \\
\hline & 80 & 5.00 & R60 & P60 & 50.70 & 2.77 & 4.41 & 4.57 & 37.55 \\
\hline
\end{tabular}

${ }^{1} \mathrm{MCC}=$ micellar casein concentrate; $\mathrm{SPI}=$ serum protein isolate; lactose $=$ anhydrous lactose; $\mathrm{DI}=$ deionized. 
na, Pall Corp., Port Washington, NY) membranes. The MCC was used as a fresh liquid ingredient in beverage formulation produced immediately before each replication of the experiment.

Serum Protein Isolate. To produce enough serum protein isolate (SPI) for the study, several batches of SPI were produced and combined before the beverage study to obtain a large batch of liquid SPI as described by Cheng et al. (2018). Briefly, MF permeate from production of MCC was concentrated using UF to a high protein (about 25\%) SPI, and the concentrate was packaged in half-gallon plastic jugs (Upstate Niagara Cooperative, Buffalo, NY) and placed in a $-20^{\circ} \mathrm{C}$ freezer for storage. Three days before formulation beverage, the frozen SPI containers were placed in a $4^{\circ} \mathrm{C}$ cooler to thaw slowly before formulation of beverages.

Cream. A cold bowl separator (model 590, Separators Inc., Indianapolis, IN) was used for raw cream separation, and then pasteurized $\left(80^{\circ} \mathrm{C}\right.$ for $\left.25 \mathrm{~s}\right)$ cream containing about $41 \%$ fat was obtained the day before formulation (North Carolina State University Dairy Enterprise System) and stored at $4^{\circ} \mathrm{C}$.

Lactose and Water. Lactose monohydrate (Hilmar 5120 IF Refined Edible Lactose 200 mesh, $25 \mathrm{~kg} / \mathrm{bag}$ ) was donated by Hilmar Ingredients (Hilmar, CA). Potable water was processed to produce deionized water using a deionizing water system (unit number: 1933-2, Mar Cor, Raleigh, NC).

\section{Beverage Formulation}

Formulations $(9,500 \mathrm{~g}$ per batch) were calculated using Microsoft Excel linear optimization solver function (Redmond, WA) as described by Misawa et al. (2016) and Cheng et al. (2018). The MCC, SPI, cream, lactose, and deionized water were used as raw ingredients. Within each fat level $(0.2,1$, or $2 \%$ fat $)$, the TP and CN\%TP were targeted at 4 TP levels $(3.00,3.67,4.34$, and $5.00 \%)$ and $5 \mathrm{CN} \% \mathrm{TP}(5,25,50,75$, and $80 \%)$, respectively. Anhydrous lactose concentration was standardized to $4.65 \%$ for all formulations. In total, there were 20 combinations of TP and CN\%TP for each fat level in one replicate, as described by Cheng et al. (2018). The experiment with 20 formulations was replicated twice at each fat level starting with freshly produced MCC and cream. Two processing runs for skim were complete in 2 different weeks and the same was done for the formulations within the 1 and $2 \%$ fat levels for a total of 6 sets ( 2 replications of each fat level with 20 formulations per replication).

Within a fat level for each replicate, 9,500 g each of 20 unpasteurized milk beverages were well mixed individually and continuously fed to a Microthermics EHVH pasteurization unit (Microthermics, Raleigh, NC) with a 2-stage homogenizer (GEA Niro Soavi, Parma, Italy) at flow rate of $2 \mathrm{~L} / \mathrm{min}$. Each beverage formulation was preheated to $60^{\circ} \mathrm{C}$, homogenized (1st stage at $17.3 \mathrm{MPa}$ and 2nd stage at $3.4 \mathrm{MPa})$, HTST pasteurized $\left(73^{\circ} \mathrm{C}\right.$ for $15 \mathrm{~s}$ ), and cooled to $10^{\circ} \mathrm{C}$, as described by Cheng et al. (2018). Pasteurized milk beverages were stored at $4^{\circ} \mathrm{C}$.

\section{Analysis Methods}

Chemical Composition and Color. Chemical composition analysis during processing, of ingredients, and calculation of formulations based on ingredient composition were conducted as described by Cheng et al. (2018). Milk protein beverages (unpasteurized and homogenized/pasteurized) were tested in duplicate using an Ultra Scan Pro Spectrophotometer (Hunter Associates Laboratory Inc., Reston, VA) at 4 and $20^{\circ} \mathrm{C}$. A water bath was used to maintain sample temperature at 4 or $20^{\circ} \mathrm{C}$. Milk beverages were measured in reflectance mode, wavelength from 360 to $750 \mathrm{~nm}$ with a $5 \mathrm{~nm}$ resolution, Illuminant $\mathrm{A}$ at a 10 degree viewer angle. Color data were collected using both Hunter L, $a$, and $b$ values and CIE L*, $a^{*}$, and $b^{*}$ values (Cheng et al., 2018). Based on a previous color methodology study (Cheng et al., 2018), Hunter L, a, and CIE b* values were reported in the current paper.

Viscosity. Milk protein beverages (unpasteurized and pasteurized/homogenized) were tested in duplicate at 4,20 , and $50^{\circ} \mathrm{C}$ using a rotational viscometer $(\mathrm{LV}$ DV2T, Brookfield Engineering Laboratories Inc., Middleboro, MA) with a jacketed enhanced UL Adapter (Brookfield Engineering Laboratories Inc.) as described by Adams et al. (2015).

Descriptive Analysis of Appearance. Descriptive analysis was conducted in accordance with the North Carolina State University Institutional Review Board for the Protection of Human Subjects in Research regulations. The milk protein beverages were evaluated for appearance within $96 \mathrm{~h}$ after processing. Appearance profiling was conducted in separate sessions with 6 of trained panelists (2 males, 4 females, ages 24-52 yr). Each panelist had a minimum of $80 \mathrm{~h}$ of prior descriptive analysis training on food appearance attributes using the Spectrum method with a 0- to 15-point intensity scale (Meilgaard et al., 2007), and at least $40 \mathrm{~h}$ of prior experience with the sensory profiling of fluid milk and dried dairy ingredients using established sensory languages (Drake et al., 2003; Croissant et al., 2007; McCarthy et al., 2017). Compusense Cloud (Guelph, Canada) was used for data collection.

Appearance profiling consisted of unpasteurized beverages at $4^{\circ} \mathrm{C}$, unpasteurized beverages at $20^{\circ} \mathrm{C}$, pasteurized/homogenized beverages at $4^{\circ} \mathrm{C}$, and pas- 
teurized/homogenized beverages at $20^{\circ} \mathrm{C}$. Appearance attributes (color intensity, whiteness, yellowness, and opacity) were adopted from previous research (Phillips et al., 1995b; Misawa et al., 2016; Lee et al., 2017; McCarthy et al., 2017). Samples (10 mL) was poured into covered $60 \mathrm{~mm} \times 15 \mathrm{~mL}$ transparent Petri dishes (Sigma-Aldrich, St. Louis, MO) with random 3-digit codes. Unpasteurized beverages were gently inverted before pouring and gently swirled before evaluation to help better distribute the fat due to the lack of homogenization. A 25.4-mm-wide black stripe was printed horizontally across the middle of a blank piece of copy paper (92 bright, paper weight: $75 \mathrm{~g} / \mathrm{m}^{2}$, size: $216 \mathrm{~mm}$ $\times 279 \mathrm{~mm}$, Staples Inc., Framingham, MA) by a HP LaserJet Enterprise P3015dn Printer equipped with a HP 55A Black Toner Cartridge (CE255A, HP Inc., Palo Alto, CA) and used as the background for the appearance evaluation. For $20^{\circ} \mathrm{C}$ sessions, samples were tempered to $20^{\circ} \mathrm{C}$ and placed on the middle of the black stripe. The evaluation of the $4^{\circ} \mathrm{C}$ sessions were the same as the $20^{\circ} \mathrm{C}$, except the $4^{\circ} \mathrm{C}$ beverages were stored in a $4^{\circ} \mathrm{C}$ walk-in cooler before evaluation and a 3-layer ice box was made to maintain the low temperature during evaluation. Crushed ice was the bottom layer, a plastic wrap was the mid layer, and the black strip paper was the top layer. Before each session, panelists were calibrated with appearance properties of water, heavy cream, MCC, and SPI ingredients using the same light source (20W, F20T12 warm white fluorescent tube light bulb, General Electric, Boston, MA). Each panelist evaluated each sample in duplicate in a randomized design. A 10-min rest was enforced following every 10 samples.

\section{Statistical Analysis}

Unpasteurized Beverages. The GLM procedure of SAS (version 9.4, SAS Institute Inc., Cary, NC) was used to determine the effect of fat $(0.2,1$, and $2 \%)$, TP $(3.0,3.67,4.34$, and $5.0 \%), \mathrm{CN} \% \mathrm{TP}(5,25,50,75$, and $80 \%$ ), measurement temperature of instrumental color (4 and $20^{\circ} \mathrm{C}$ ), and replicate on beverage color measured instrumentally. The effect of the same composition parameters at appearance evaluation temperatures of 4 and $20^{\circ} \mathrm{C}$ on sensory appearance was also determined. All interactions of these parameters were included in the model. Fat, TP, and temperature were treated as categorical variables, whereas $\mathrm{CN} \% \mathrm{TP}$ was handled as a continuous variable. The CN\%TP data were transformed (named CNTPT) by mean-centering (Misawa et al., 2016) to avoid co-linearity effects on statistical analysis (Glantz and Slinker, 2001). If the $F$-value for the full model was significant $(P<0.05)$, then signifi- cance $(P<0.05)$ of each parameter and their interactions was determined. The effects of fat, TP (protein), heat treatment, temperature of color measurement (temperature), replicate, and their interactions were tested for significance using the interaction term of fat $\times$ protein $\times$ temperature $\times$ replicate as the error term, whereas the effects (linear and quadratic) of the continuous variable of $\mathrm{CN} \% \mathrm{TP}$ and their interactions with the categorical variables were tested for significance using the full model error. A stepwise process was done to remove all nonsignificant terms from the model to produce a final reduced model and type III sum of squares table. To understand the relative amount of total variation explained by each parameter or interaction of parameters on each instrumental color and each sensory appearance metric, the type III sum of squares value for each term was divided by the total type III sum of squares of the significant terms in the model and multiplied by 100 . The term for fat and its related interaction terms in the model were removed from the model when analyzing data to determine the effect of each parameter within each fat level.

Unpasteurized and Pasteurized Beverages. The SAS models (across all fat levels) described above were modified by adding a term of heat treatment (homogenized and pasteurized) and its interaction terms with composition parameters to determine the effect of heat treatment on instrumental color, instrumental viscosity $\left(4,20\right.$, and $\left.50^{\circ} \mathrm{C}\right)$, and sensory appearance for unpasteurized and pasteurized/homogenized milk proteinbased beverages.

Principal component analysis and cluster analysis (using k-means) were also conducted using XLSTAT (Addinsoft, Paris, France) on both instrumental and sensory measures of beverage color. The goal of the cluster analysis was to determine if there were subpopulations of formulations that were distinct from each other. This result would guide how subpopulations of beverage formulations would be grouped for development of within subpopulation specific regression (linear, quadratic, and multiple linear) models to predict of sensory whiteness and sensory yellowness from instrumental color measures. When a very different subpopulation of formulations was identified using the biplot analysis, that group was removed and the biplot was redone for the subpopulation group of formulations. Linear, quadratic, and multiple linear regressions (MLR) were also conducted using Excel (Microsoft, Redmond, WA) data analysis to generate the prediction models of sensory whiteness and sensory yellowness by using single instrumental parameters (L or $\mathrm{b}^{*}$ values) and multiple instrumental parameters (L, $\mathrm{a}$, and $\mathrm{b}^{*}$ values). 
Table 2. Hunter L values at a 10 degree viewer angle (LHA10) using illuminant A, sensory whiteness, and sensory opacity of unpasteurized milk protein beverages: relative percentage of type III sum of squares (for factors with $P<0.05$ ) explained by model factors (fat $=$ fat level with $0.2,1$, and $2 \%$ fat; prot $=$ milk true protein with $3.00,3.67,4.34$, and $5.00 \%$; temp = temperature of color measurement with 4 and $20^{\circ} \mathrm{C}$; rep $=$ replicate; $\mathrm{CNTPT}=$ casein as a percentage of true protein transformed with $5,25,50,75$, and $80 \%)^{1}$

\begin{tabular}{|c|c|c|c|}
\hline Factor & LHA10 & Whiteness & Opacity \\
\hline Fat & 1.34 & 2.76 & 9.17 \\
\hline Prot & 0.33 & 7.05 & 2.63 \\
\hline Temp & 0.23 & NS & NS \\
\hline Rep & 0.08 & NS & NS \\
\hline Fat $\times$ prot & 0.35 & 0.22 & 0.65 \\
\hline Fat $\times$ temp & 0.36 & NS & 0.07 \\
\hline Fat $\times$ rep & 0.09 & 0.02 & 0.02 \\
\hline Prot $\times$ temp & 0.10 & 0.01 & 0.10 \\
\hline Prot $\times$ rep & NS & 0.01 & 0.05 \\
\hline Fat $\times$ prot $\times$ temp & NS & NS & 0.05 \\
\hline Fat $\times$ prot $\times$ rep & 0.18 & 0.03 & 0.04 \\
\hline Fat $\times$ prot $\times$ temp $\times$ rep & $0.01^{\mathrm{NS}}$ & NS & 0.09 \\
\hline CNTPT & 65.50 & 87.07 & 77.67 \\
\hline CNTPT $\times$ fat & 15.22 & 0.17 & 3.13 \\
\hline CNTPT $\times$ prot & 0.11 & 0.14 & 0.10 \\
\hline CNTPT $\times$ temp & 0.18 & NS & NS \\
\hline $\mathrm{CNTPT} \times$ rep & NS & 0.01 & 0.03 \\
\hline CNTPT $\times$ fat $\times$ prot & $0.09^{\mathrm{NS}}$ & NS & NS \\
\hline CNTPT $\times$ fat $\times$ temp & NS & 0.11 & 0.31 \\
\hline $\mathrm{CNTPT} \times \mathrm{CNTPT}$ & 9.51 & 1.53 & 4.50 \\
\hline $\mathrm{CNTPT} \times \mathrm{CNTPT} \times$ fat & 5.80 & 0.06 & 0.72 \\
\hline CNTPT $\times$ CNTPT $\times$ prot & 0.18 & 0.68 & 0.10 \\
\hline CNTPT $\times$ CNTPT $\times$ temp & 0.21 & NS & NS \\
\hline $\mathrm{CNTPT} \times \mathrm{CNTPT} \times$ fat $\times$ prot & 0.14 & 0.08 & 0.43 \\
\hline Sum $(\%)$ & 100.00 & 100.00 & 100.00 \\
\hline $\mathrm{R}^{2}$ & 0.98 & 0.97 & 0.96 \\
\hline $\mathrm{N}$ & 480 & 2,880 & 2,880 \\
\hline
\end{tabular}

${ }^{1} \mathrm{NS}: P>0.05$.

\section{RESULTS AND DISCUSSION}

\section{Unpasteurized Beverage Formulations}

$L$ Values (Whiteness). Whiteness of milk-based beverages is produced by reflectance of all wavelengths of light back to the observer by particles in a beverage such as fat droplets and casein micelles (Walstra, 1965; Holt, 1975). The linear component of CNTPT explained about $65.50 \%$ of the total variation of $\mathrm{L}$ values followed by the interaction of CNTPT $\times$ fat $(15.22 \%)$, the quadratic component of CNTPT $\times$ CNTPT $(9.51 \%)$, and the interaction of CNTPT $\times$ CNTPT $\times$ fat $(5.80 \%)$ across fat levels (Table 2) with $96.03 \%$ of the total variation explained by the model. Increasing $\mathrm{CN} \% \mathrm{TP}$ from 5 to $80 \%$ increased the $\mathrm{L}$ values more in the lower fat level unpasteurized beverages than it did at higher fat level (Figure 1A) as indicated by the CNTPT $\times$ fat and CNTPT $\times$ CNTPT $\times$ fat interactions $(P<0.05$, Table 2). Change in CN\% TP had a more quadratic effect on the $0.2 \%$ fat unpasteurized beverages than on the 1 and $2 \%$ ones (Figure 1A). This finding confirmed the results from Misawa et al. (2016) that L values increased as the CN\% TP increased due to the increase of concentration of light scattering casein micelles in beverages. The effect of $\mathrm{CN} \% \mathrm{TP}$ on $\mathrm{L}$ values was more profound in the lower fat level unpasteurized beverages because the light scattering in $0.2 \%$ fat unpasteurized beverages primarily came from the casein micelles, whereas the light scattering in 1 and $2 \%$ fat beverages came from 2 sources: casein micelles and fat globules, and their effects were not additive (Quiñones et al., 1997, 1998; Misawa et al., 2016).

Sensory Whiteness. Across fat levels, the majority of the total variation of sensory whiteness was explained by variation in CNTPT $(87.07 \%)$, whereas $7.05 \%$ was explained by variation in protein and an additional $3.45 \%$ from all the fat-related terms (Table 2) with $97.62 \%$ of the total variation explained by the model. Increasing CN\% TP from 5 to $80 \%$ increased sensory whiteness in a similar pattern regardless of the fat content in the raw products (Figure 1B). This result was consistent with the report by Misawa et al. (2016) for pasteurized milk protein beverages. In contrast, the quadratic effect of increasing CN\% TP and the interaction with fat was not as strong for sensory whiteness as seen in the instrumental $\mathrm{L}$ value data. In the unpasteurized beverages in the present study, increasing CN\%TP over the range from 5 to $80 \%$ had a larger effect on sensory whiteness than increasing fat content 
from 0.2 to $2 \%$, particularly in the lower fat beverages (Table 2 and Figure 1B).

Sensory Opacity. Variation in CNTPT, fat, and CNTPT $\times$ fat explained $77.67,9.17$, and $3.13 \%$ of the total variation in sensory opacity across all fat levels (Table 2) with $89.97 \%$ of the total variation explained by the model. Increasing CN\%TP from 5 to $80 \%$ increased the sensory opacity more in the lower fat level unpasteurized products while increasing fat from 0.2 to $2 \%$ increased the sensory opacity less in the higher $\mathrm{CN} \% \mathrm{TP}$ in unpasteurized products (Figure 1C) than

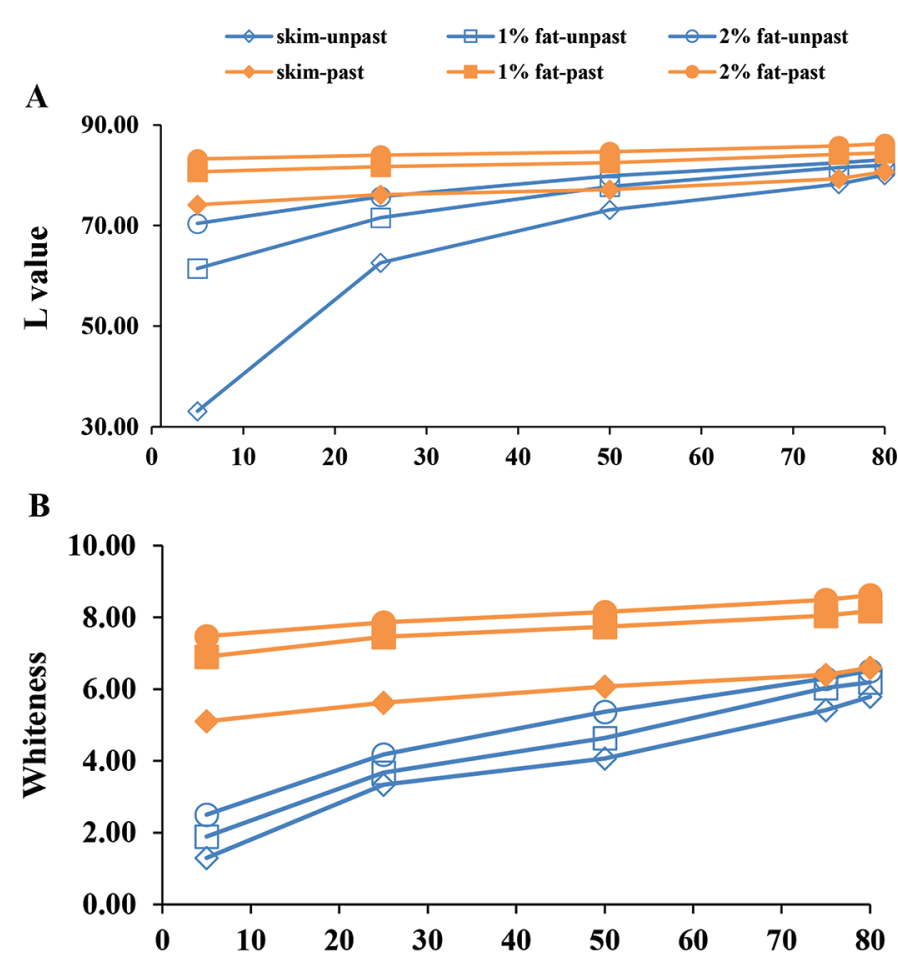

C

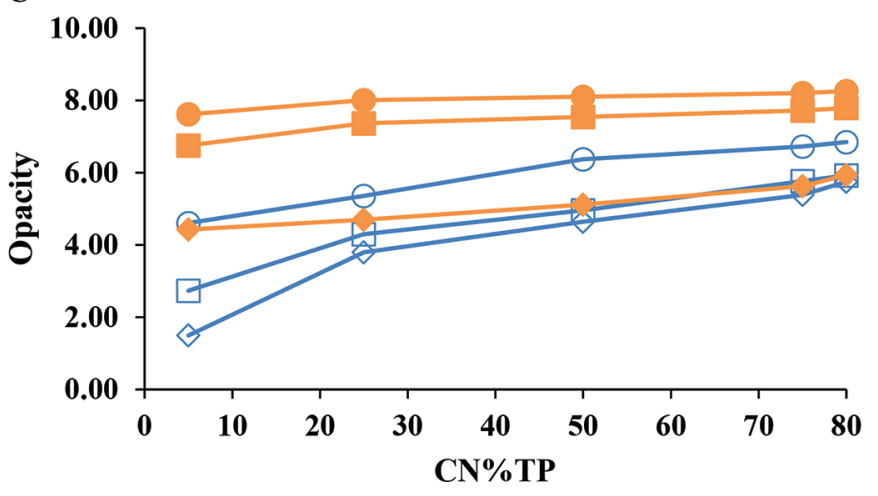

Figure 1. (A) Hunter $\mathrm{L}$ values $\left(4\right.$ and $\left.20^{\circ} \mathrm{C}\right)$ at 10 degree viewer angle using illuminant A, (B) sensory whiteness, and (C) sensory opacity for unpasteurized (unpast) and pasteurized (past) milk protein beverages with different fat levels (skim, $1 \%$ fat, and $2 \%$ fat) as a function of casein as a percentage of true protein $(\mathrm{CN} \% \mathrm{TP})$. in lower $\mathrm{CN} \% \mathrm{TP}$ unpasteurized beverages. Increases in fat levels that increased sensory opacity were also reported by Misawa et al. (2016). The quadratic effect of $\mathrm{CN} \% \mathrm{TP}$ had a stronger influence on skim beverages than 1 and $2 \%$ fat beverages (CNTPT $\times$ fat interaction $P<0.05$, Table 2 and Figure $1 \mathrm{C})$.

\section{All Fat Levels: a Values, b* Values, and Sensory Color Intensity and Yellowness}

a Values (Redness-Greenness). The sensory perception of redness and greenness in milk-based beverages occurs when light travels through the skim portion of milk and the concentration of light scattering particles is low (e.g., low fat and low casein). The perception of redness or greenness is due to compounds in the skim milk portion of milk that absorb light at specific wavelengths allowing reflectance of green or red light. Typical light absorbing compounds in the skim portion of the milk-based beverages are lactoferrin (redness) and riboflavin (greenness). Positive a values indicate redness and negative a values indicate greenness, and a values near zero indicate that perceived redness or greenness will be low. In general, a values for all beverages were near zero (i.e., not strongly green or red), with the skim beverages having a tendency to be more green than those with 1 or $2 \%$ fat (Figure $2 \mathrm{~A}$ ).

Variation in fat, CNTPT, and CNTPT $\times$ CNTPT, respectively, contributed to $48.84,28.77$, and $11.01 \%$ of the total variation of a values for the unpasteurized products across fat levels (Table 3 ) with $88.62 \%$ of the total variation explained by the model. Increases in fat level from 0.2 to $1 \%$ increased the a values (i.e., redness) of the unpasteurized beverages more than increases in the fat level from 1 to $2 \%$ did (Figure 2A). Fat had the largest effect on a values because increases in fat level presented more fat globules on the surface of the beverages and more light at all wavelengths was reflected back and less light was absorbed by green compounds (such as: riboflavin) in the serum phase (Misawa et al., 2016). The reflection of light at all wavelengths was already relatively high in the $1 \%$ fat beverages and increasing fat to $2 \%$ did not increase the light reflection to the extent as increasing fat from 0.2 to $1 \%$ [i.e., interactions $(P<0.05)$ of fat with linear and quadratic terms for casein and protein; Table 3]. The linear and quadratic effects of increasing $\mathrm{CN} \% \mathrm{TP}$ caused a values of the unpasteurized beverages to decrease (Figure 2A) due to the increases in contribution of green components in the beverages (Misawa et al., 2016).

$b^{*}$ Values (Yellowness-Blueness). The perception of yellowness or blueness is primarily due to the presence or absence of compounds in the fat portion of milk that absorbed light at specific wavelengths allow- 

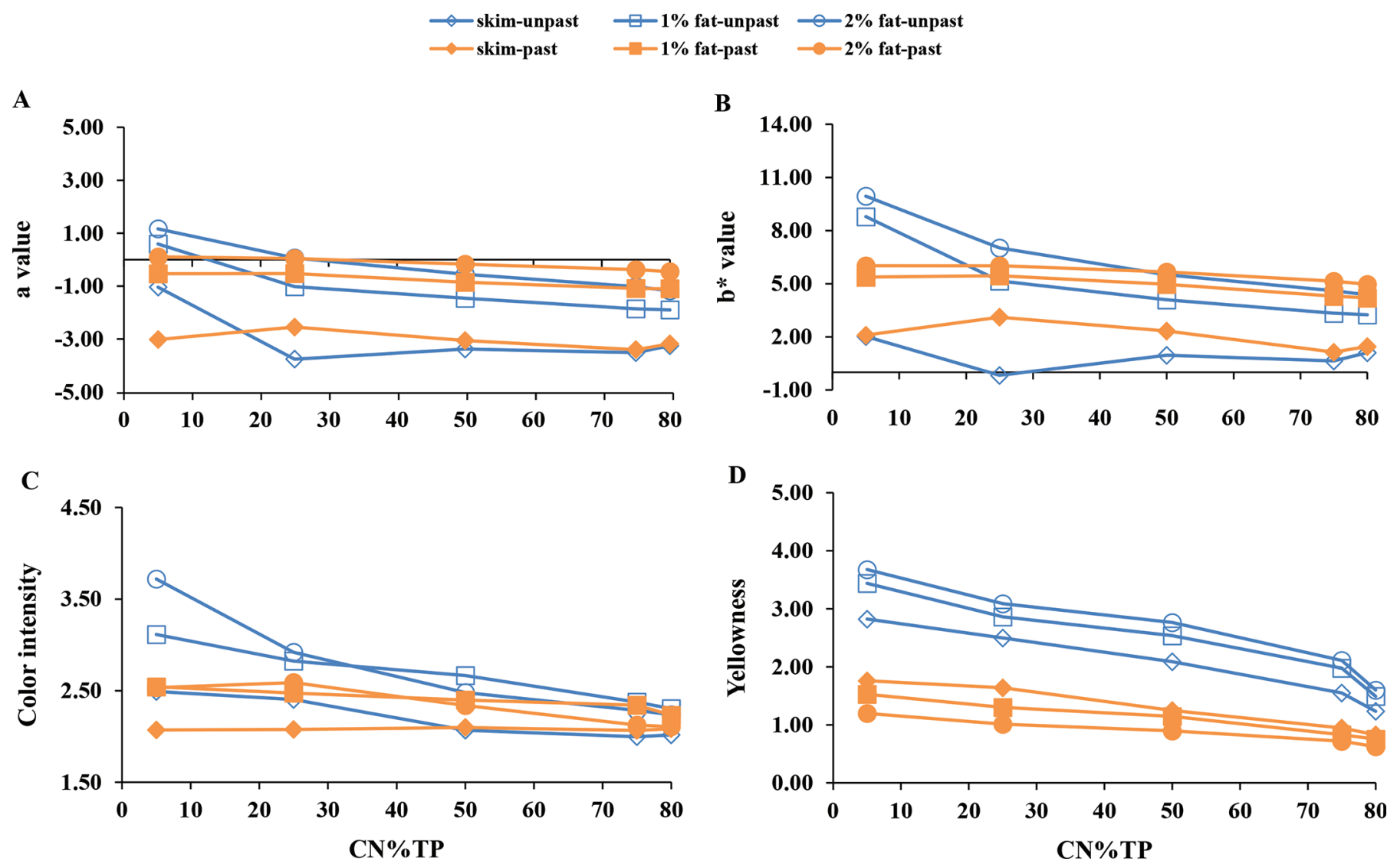

Figure 2. (A) Hunter a values $\left(4\right.$ and $\left.20^{\circ} \mathrm{C}\right)$ at 10 degree viewer angle using illuminant $\mathrm{A}$, (B) CIE b* values $\left(4\right.$ and $\left.20^{\circ} \mathrm{C}\right)$ at 10 degree viewer angle using illuminant A, (C) sensory color intensity, and (D) sensory yellowness for unpasteurized (unpast) and pasteurized (past) milk protein beverages with different fat levels (skim, $1 \%$ fat, and $2 \%$ fat) as a function of casein as a percentage of true protein (CN\% TP).

ing reflectance of yellow light. Typical light-absorbing compounds in the fat portion of the milk-based beverages are carotenoids that will produce a yellow/orange color perception. Positive $b^{*}$ values indicate yellowness and negative $b^{*}$ values indicate blueness, and $b^{*}$ values near zero indicate that perceived yellowness or blueness will be low. In general, $b^{*}$ values for all beverages increased by large amounts when fat concentration in the beverages increased, with yellowness of skim milk being low (Figure 2B).

Across all fat levels, 38.35, 29.86, 14.73, and 8.91\% of the total variation of $b^{*}$ values was explained by the effects of fat, CNTPT, CNTPT $\times$ fat, and CNTPT $\times$ CNTPT, respectively, in unpasteurized beverages (Table 3) with $91.85 \%$ of the total variation explained by the model. Increasing fat level from 0.2 to $1 \%$ increased the $\mathrm{b}^{*}$ values more than increasing fat level from 1 to $2 \%$ did (Figure 2B) in unpasteurized beverages. The reason for the increases in fat level causing the increases in $b^{*}$ values could be due to the presence of carotenoids in milk fat (Johnson, 1974; Misawa et al., 2016). The $b^{*}$ values decreased with increasing
CN\%TP and the decrease in $b^{*}$ values was larger in the higher fat unpasteurized beverages (Figure 2B). The CN\%TP had a quadratic effect on $b^{*}$ values for unpasteurized beverages with increasing CN\%TP decreasing $\mathrm{b}^{*}$ value more in 1 and $2 \%$ fat unpasteurized beverages than in skim beverages (Figure 2B). The decrease of $b^{*}$ values as CN\%TP increased could have been caused by increased casein micelle concentration in the skim portion of unpasteurized beverages causing more light at all wavelengths to be reflected before it had a chance to enter fat globules and be absorbed by carotenoids to produce a perception of yellow color. This assumption is supported by the fact that when the CN\% TP becomes very low (i.e., going from 25 to $5 \% \mathrm{CN} \% \mathrm{TP}$ ), yellowness of 1 and $2 \%$ fat beverages increased quickly due to much more light penetrating fat droplets (Figure $2 \mathrm{~B}$, unpasteurized treatments).

Sensory Color Intensity. The effects of CNTPT, fat, and CNTPT $\times$ fat explained 65.77, 9.92, and 8.54\%, respectively, of the total variation of color intensity across fat levels for the unpasteurized beverages (Table 3) with $84.23 \%$ of the total variation explained by the 
Table 3. Hunter a value (aHA10) and International Commission on Illumination $b^{*}$ value (bCA10) at a 10 degree viewer angle using illuminant A, sensory color intensity and sensory yellowness of unpasteurized milk protein beverages: relative percentage of type III sum of squares (for factors with $P<0.05$ ) explained by model factors $($ fat $=$ fat level with $0.2,1$, and $2 \%$ fat; prot $=$ milk true protein with $3.00,3.67,4.34$, and $5.00 \%$; temp $=$ temperature of color measurement with 4 and $20^{\circ} \mathrm{C}$; rep $=$ replicate; CNTPT $=$ casein as a percentage of true protein with $5,25,50,75$, and $80 \%$ transformed $)^{1}$

\begin{tabular}{|c|c|c|c|c|}
\hline Factor & aHA10 & bCA10 & Color intensity & Yellowness \\
\hline Fat & 48.84 & 38.35 & 9.92 & 4.50 \\
\hline Prot & 2.11 & 1.72 & $0.11^{\mathrm{NS}}$ & 2.16 \\
\hline Temp & 0.06 & 0.20 & $0.08^{\mathrm{NS}}$ & 0.18 \\
\hline Rep & NS & NS & $0.01^{\mathrm{NS}}$ & NS \\
\hline Fat $\times$ prot & 1.21 & 2.20 & 0.60 & 0.33 \\
\hline Fat $\times$ temp & 1.32 & 0.84 & 0.50 & NS \\
\hline Fat $\times$ rep & NS & 0.15 & 0.17 & 0.22 \\
\hline Prot $\times$ temp & NS & NS & 0.19 & $0.03^{\mathrm{NS}}$ \\
\hline Prot $\times$ rep & NS & NS & 0.44 & NS \\
\hline Temp $\times$ rep & NS & NS & 0.06 & 0.05 \\
\hline Fat $\times$ prot $\times$ temp & NS & NS & 0.18 & 0.06 \\
\hline Fat $\times$ prot $\times$ rep & 0.44 & 0.37 & 0.19 & NS \\
\hline Fat $\times$ temp $\times$ rep & NS & NS & 0.35 & 0.06 \\
\hline Prot $\times$ temp $\times$ rep & NS & NS & 0.12 & 0.10 \\
\hline Fat $\times$ prot $\times$ temp $\times$ rep & $0.06^{\mathrm{NS}}$ & $0.02^{\mathrm{NS}}$ & 0.28 & 0.15 \\
\hline CNTPT & 28.77 & 29.86 & 65.77 & 90.10 \\
\hline $\mathrm{CNTPT} \times$ fat & 1.90 & 14.73 & 8.54 & 0.59 \\
\hline CNTPT $\times$ prot & NS & 0.22 & 0.15 & 0.08 \\
\hline CNTPT $\times$ temp & 0.36 & 0.41 & 0.32 & NS \\
\hline $\mathrm{CNTPT} \times$ rep & NS & NS & 0.55 & 0.04 \\
\hline CNTPT $\times$ fat $\times$ prot & NS & NS & 0.21 & 0.10 \\
\hline $\mathrm{CNTPT} \times$ fat $\times$ temp & 0.20 & 0.21 & 0.50 & 0.10 \\
\hline CNTPT $\times$ fat $\times$ rep & NS & NS & 1.48 & NS \\
\hline $\mathrm{CNTPT} \times$ prot $\times$ temp & NS & NS & 0.10 & NS \\
\hline $\mathrm{CNTPT} \times$ temp $\times$ rep & NS & NS & 0.10 & NS \\
\hline CNTPT $\times$ prot $\times$ rep & NS & NS & 0.19 & NS \\
\hline $\mathrm{CNTPT} \times \mathrm{CNTPT}$ & 11.01 & 8.91 & 3.30 & 0.88 \\
\hline $\mathrm{CNTPT} \times \mathrm{CNTPT} \times$ fat & 2.98 & 0.38 & 3.79 & NS \\
\hline $\mathrm{CNTPT} \times \mathrm{CNTPT} \times$ prot & $0.14^{\mathrm{NS}}$ & 0.15 & 0.24 & 0.08 \\
\hline $\mathrm{CNTPT} \times \mathrm{CNTPT} \times$ temp & NS & NS & NS & 0.07 \\
\hline CNTPT $\times$ CNTPT $\times$ rep & NS & NS & 0.23 & NS \\
\hline $\mathrm{CNTPT} \times \mathrm{CNTPT} \times$ fat $\times$ prot & 0.59 & 0.92 & 0.52 & 0.11 \\
\hline $\mathrm{CNTPT} \times \mathrm{CNTPT} \times$ fat $\times$ temp & NS & 0.35 & 0.04 & NS \\
\hline $\mathrm{CNTPT} \times \mathrm{CNTPT} \times$ fat $\times$ rep & NS & NS & 0.12 & NS \\
\hline $\mathrm{CNTPT} \times \mathrm{CNTPT} \times$ prot $\times$ temp & NS & NS & 0.21 & NS \\
\hline $\mathrm{CNTPT} \times \mathrm{CNTPT} \times$ prot $\times$ rep & NS & NS & 0.42 & NS \\
\hline Sum $(\%)$ & 100.00 & 100.00 & 100.00 & 100.00 \\
\hline $\mathrm{R}^{2}$ & 0.96 & 0.98 & 0.91 & 0.90 \\
\hline $\mathrm{N}$ & 480 & 480 & 2,880 & 2,880 \\
\hline
\end{tabular}

${ }^{1} \mathrm{NS}: P>0.05$

model. As CN\%TP increased color intensity decreased and the decrease in color intensity was large in higher fat unpasteurized beverages than in lower unpasteurized beverages (Figure 2C). Color intensity increased with increasing fat content in unpasteurized beverages (Figure 2C).

Sensory Yellowness. Variation in CNTPT explained $90.1 \%$ of the total variation of sensory yellowness, whereas fat level explained $4.5 \%$ of variation (Table 3 ) in unpasteurized beverages with $94.6 \%$ of the total variation explained by the model. Unpasteurized beverages with lower fat content were less yellow (Figure 2D). This could due to the decreases of fat soluble carotenoids absorbing light (Misawa et al., 2016). As CN\%TP increased, sensory yellowness decreased for all fat levels in unpasteurized beverages (Figure 2D), which showed the same trend in the $\mathrm{b}^{*}$ values (Figure 2B).

\section{Within Fat Levels: L Values and Sensory Whiteness and Opacity}

$L$ Values (Whiteness). The linear effect of CNTPT explained $79.34,89.38$, and $92.82 \%$ of the total variation of $\mathrm{L}$ values for the $0.2,1$, and $2 \%$ fat raw products, respectively, and its quadratic term $($ CNTPT $\times$ CNTPT) contributed to $18.17,7.79$, and $3.91 \%$ of the total variation of $\mathrm{L}$ values in unpasteurized beverages, respectively (Table 4). The $\mathrm{L}$ values increased with increasing CN\%TP at each fat level, but the increase 
Table 4. Hunter L values at a 10 degree viewer angle (LHA10) using illuminant A, sensory whiteness, and sensory opacity of unpasteurized milk protein beverages: relative percentage of type III sum of squares (for factors with $P<0.05$ ) explained by model factors (prot $=$ milk true protein with $3.00,3.67,4.34$, and $5.00 \%$; temp = temperature of sensory appearance evaluation with 4 and $20^{\circ} \mathrm{C}$; rep $=$ replicate; CNTPT $=$ casein as a percentage of true protein with $5,25,50,75$, and $80 \%$ transformed) at 3 fat levels $(0.2,1 \text {, and } 2 \%)^{1}$

\begin{tabular}{|c|c|c|c|c|c|c|c|c|c|}
\hline \multirow[b]{2}{*}{ Factor } & \multicolumn{3}{|c|}{ LHA10 } & \multicolumn{3}{|c|}{ Whiteness } & \multicolumn{3}{|c|}{ Opacity } \\
\hline & $\begin{array}{c}0.2 \% \\
\text { Fat }\end{array}$ & $\begin{array}{l}1 \% \\
\text { Fat }\end{array}$ & $\begin{array}{l}2 \% \\
\text { Fat }\end{array}$ & $\begin{array}{c}0.2 \% \\
\text { Fat }\end{array}$ & $\begin{array}{l}1 \% \\
\text { Fat }\end{array}$ & $\begin{array}{l}2 \% \\
\text { Fat }\end{array}$ & $\begin{array}{c}0.2 \% \\
\text { Fat }\end{array}$ & $\begin{array}{l}1 \% \\
\text { Fat }\end{array}$ & $\begin{array}{l}2 \% \\
\text { Fat }\end{array}$ \\
\hline Temp & 0.71 & 0.16 & NS & NS & NS & NS & $0.06^{\mathrm{NS}}$ & NS & $0.03^{\mathrm{NS}}$ \\
\hline Rep & 0.01 & 0.71 & 0.69 & NS & 0.08 & NS & $0.04^{\mathrm{NS}}$ & 0.02 & NS \\
\hline Prot $\times$ temp & NS & NS & NS & NS & 0.06 & 0.06 & 0.45 & NS & 0.09 \\
\hline Prot $\times$ temp $\times$ rep & NS & NS & 0.13 & $0.03^{\mathrm{NS}}$ & $0.02^{\mathrm{NS}}$ & NS & 0.14 & $0.08^{\mathrm{NS}}$ & 0.07 \\
\hline CNTPT & 79.34 & 89.38 & 92.82 & 87.31 & 92.59 & 89.05 & 85.18 & 86.04 & 93.47 \\
\hline $\mathrm{CNTPT} \times$ prot & NS & 0.31 & 0.60 & 0.36 & 0.34 & 0.04 & 0.40 & 0.63 & 0.45 \\
\hline $\mathrm{CNTPT} \times$ temp & NS & 0.63 & 1.14 & NS & NS & NS & NS & NS & 0.02 \\
\hline $\mathrm{CNTPT} \times$ rep & NS & NS & NS & NS & NS & 0.01 & 0.05 & NS & 0.08 \\
\hline CNTPT $\times$ prot $\times$ temp & NS & NS & 0.04 & NS & NS & 0.03 & NS & NS & 0.07 \\
\hline $\mathrm{CNTPT} \times$ temp $\times$ rep & NS & NS & NS & NS & NS & NS & NS & NS & 0.05 \\
\hline $\mathrm{CNTPT} \times \mathrm{CNTPT} \times$ temp $\times$ rep & NS & NS & NS & NS & NS & 0.02 & NS & NS & NS \\
\hline $\mathrm{CNTPT} \times \mathrm{CNTPT} \times$ prot $\times$ rep & NS & NS & NS & NS & NS & 0.02 & 0.18 & NS & 0.07 \\
\hline Sum $(\%)$ & 100.00 & 100.00 & 100.00 & 100.00 & 100.00 & 100.00 & 100.00 & 100.00 & 100.00 \\
\hline $\mathrm{R}^{2}$ & 0.97 & 1.00 & 1.00 & 0.96 & 0.96 & 0.99 & 0.95 & 0.96 & 0.97 \\
\hline $\mathrm{N}$ & 160 & 160 & 160 & 960 & 960 & 960 & 960 & 960 & 960 \\
\hline
\end{tabular}

${ }^{1} \mathrm{NS}: P>0.05$.

was larger in lower CN\% TP level unpasteurized beverages (Figure 1A). This could be due to the fact that the concentration of light scattering casein micelles was relatively low and a slight increase in casein micelle concentration could cause a rapid increase in light scattering and $\mathrm{L}$ values, whereas in higher $\mathrm{CN} \% \mathrm{TP}$ unpasteurized beverages, the light scattering was already high and increases in casein micelle concentration still increased the $\mathrm{L}$ values, but not to the extent as in the beverages with lower CN\%TP.

Sensory Whiteness. Variation in CNTPT explained $87.31,92.59$, and $89.05 \%$ of the total variation of sensory whiteness for $0.2,1$, and $2 \%$ fat unpasteurized beverages, respectively, and protein explained $9.92,5.33$, and $6.96 \%$ of variation in sensory whiteness, respectively (Table 4). Sensory whiteness increased linearly with increasing CN\% TP within each fat level in the unpasteurized beverages (Figure 1B). Misawa et al. (2016) also reported that an increase in CN\%TP had a strong effect to increase sensory whiteness in 1 and $2 \%$ pasteurized milk protein beverages.

Sensory Opacity. Variation in CNTPT and CNTPT $\times$ CNTPT explained 85.18 and $7.71 \%$ of the total variation of opacity for the $0.2 \%$ fat, 86.04 and $3.68 \%$ for the $1 \%$ fat, and 93.47 and $3.36 \%$ for the $2.00 \%$ fat unpasteurized beverages (Table 4). As CN\%TP in- creased, sensory opacity within each fat level increased for unpasteurized beverages (Figure 1C), which also confirmed results from Misawa et al. (2016).

\section{Within Fat Levels: a and $b$ * Values and Sensory Color Intensity and Yellowness}

In general, the $\mathrm{R}^{2}$ values for ANOVA models to determine the effect of variation in composition parameters on $\mathrm{a}$ and $\mathrm{b}^{*}$ values and sensory color intensity and yellowness were lower than those for instrument and sensory metrics of whiteness and opacity. When $\mathrm{R}^{2}$ values for the total model are lower, the ability of the ANOVA to correctly partition variation and assign that variation gets weaker. This was the case for models in this section that ranged in $\mathrm{R}^{2}$ values from 0.68 to 0.99 .

a Values (Redness-Greenness). Within the skim ( $0.2 \%$ fat) unpasteurized beverages, the effects of CNTPT, CNTPT $\times$ CNTPT, and protein explained $19.88,54.08$, and $15.12 \%$ of the total variation of a values, respectively (Table 5 ) with a $R^{2}$ value of 0.80 . When the $\mathrm{R}^{2}$ value for the model was low, the model had a more difficult time separating the effect of the effect of variation in protein concentration and $\mathrm{CN} \% \mathrm{TP}$ on a values. While within the $1 \%$ fat unpasteurized beverages, CNTPT explained $76.56 \%$ of the total variation 
of a values followed by CNTPT $\times$ CNTPT $(15.54 \%)$ and protein $(5.68 \%)$ with a $\mathrm{R}^{2}$ value of 0.96 (Table 5 ). Within the $2 \%$ fat unpasteurized beverages, CNTPT explained $91.08 \%$ of the total variation of a values followed by CNTPT $\times$ CNTPT $(5.01 \%)$ with an $\mathrm{R}^{2}$ value of 0.99 (Table 5). Generally, a values decreased with increasing CN\%TP within each fat level in unpasteurized beverages, which could be due to increased absorption of light by riboflavin or other green appearing components in the serum phase of the milk protein beverages (Misawa et al., 2016).

$b^{*}$ Values (Yellowness-Blueness). Again, for the $0.2 \%$ fat level unpasteurized beverages, the $\mathrm{R}^{2}$ value for the ANOVA model was low (i.e., 0.72) and the model had a difficult time separating the effect of variation of protein level and variation in $\mathrm{CN} \% \mathrm{TP}$ on $\mathrm{b}^{*}$ value. In the 1 and $2 \%$ fat level unpasteurized beverages, the $\mathrm{R}^{2}$ values were higher (0.97 and 0.99 , respectively) and there was a strong effect of the linear and quadratic terms for $\mathrm{CN} \% \mathrm{TP}$ on $\mathrm{b}^{*}$ value (Table 5). As $\mathrm{CN} \% \mathrm{TP}$ in the unpasteurized beverages increased, $\mathrm{b}^{*}$ value decreased, with larger decreases in the 1 and $2 \%$ fat unpasteurized beverages (Figure 2B). Increases in $\mathrm{CN} \% \mathrm{TP}$ resulted in more casein micelles at the interface of the milk fat globule, and blocked the light path into the fat globule and decreased the $\mathrm{b}^{*}$ values.

Sensory Color Intensity. Variation in CNTPT explained $82.58,69.86$, and $83.99 \%$ of the total variation of color intensity for the $0.2,1$, and $2 \%$ fat unpasteurized beverages, respectively (Table 5). As CN\% TP increased, sensory color intensity decreased with a larger decrease from 5 to $25 \% \mathrm{CN} \% \mathrm{TP}$ than from 25 to $80 \%$ in unpasteurized beverages (Figure 2C).

Sensory Yellowness. Within each fat level, variation in CNTPT explained 94.0, 94.89, and 92.82\% of the total variation of yellowness for the $0.2,1$, and $2 \%$ fat unpasteurized beverages, respectively (Table 5). As previously reported by Misawa et al. (2016), as CN\% TP increased, sensory yellowness decreased at all fat levels (Figure 2D) in unpasteurized milk-based beverages.

\section{Combined Unpasteurized and Pasteurized Beverage Formulations}

$L$ Values (Whiteness). The effect of heat of pasteurization and homogenization on the total variation of $\mathrm{L}$ values is reflected by the sum of all significant terms in the model that include heat. The most important of these terms, heat, CNTPT $\times$ heat, CNTPT $\times$ fat $\times$ heat, CNTPT $\times$ CNTPT $\times$ heat, and CNTPT $\times$ CNTPT $\times$ fat $\times$ heat, contributed to the total variation of $\mathrm{L}$ values across fat levels in unpasteurized and pasteurized beverages (Table 6). Heat treatment (homogenization and pasteurization) increased the $\mathrm{L}$ val- ues more in the products with lower fat levels and lower CN\%TP levels than in products with higher CN\%TP (Figure 1A). This may be due to the heat-induced denaturation of noncasein proteins that interact with casein micelles to build larger light scattering protein aggregates in the pasteurized, homogenized skim milk beverages.

Sensory Whiteness. Variation in CNTPT, heat, and CNTPT $\times$ heat had the largest effect on sensory whiteness in unpasteurized and pasteurized milk-based beverages (Table 6). Heat treatment increased the whiteness of all beverages at all fat levels and the effect was larger at low CN\% TP than at high CN\%TP (Figure 1B). Heat and homogenization increased the sensory whiteness more for beverages containing 1 or $2 \%$ fat than in beverages containing $0.2 \%$ fat (Figure 1B).

Sensory Opacity. Variation in fat (21.88\%), heat (15.98\%), CNTPT (36.51\%), and CNTPT $\times$ heat (8.89\%) explained most of the variation in opacity among unpasteurized and pasteurized milk beverages (Table 6). Heat treatment increased the sensory opacity more in the products with higher fat levels and lower CN\%TP (Figure 1C).

Generally, heat (pasteurization and homogenization) increased the L values, sensory whiteness, and sensory opacity more in the skim beverages than it did in the 1 and $2 \%$ fat beverages (Figure 1). More specifically, pasteurization caused the denaturation and attachment of serum protein to the casein micelles, and homogenization generated a more uniform fat distributed emulsion with a larger surface area and more casein micelles at the interface of the fat globule and the serum phase of the milk beverages. The effects on $\mathrm{L}$ values of increasing $\mathrm{CN}$ and fat content at the same time were not additive (Quiñones et al., 1998; Misawa et al., 2016). The pasteurization derived denaturation of milk serum proteins may have affected light scattering of the skim beverages more, whereas both pasteurization and homogenization could influence whiteness in the 1 and $2 \%$ fat beverages.

\section{All Fat Levels: a Values, b* Values, Color Intensity, and Yellowness}

a Values (Redness-Greenness). Variation in fat content explained more than $50 \%$ of the variation in a values (Table 7 ). The effects of heat, $\mathrm{CNTPT} \times$ heat, and CNTPT $\times$ CNTPT $\times$ heat explained 4.96, 3.83, and $5.01 \%$ of the total variation of a values across fat levels (Table 7 and Figure 2A).

$b^{*}$ Values (Yellowness-Blueness). Variation in fat content explained about $38 \%$ of the variation in $b^{*}$ values (Table 7 ), with lower fat content beverages 
MILK PROTEIN BEVERAGES

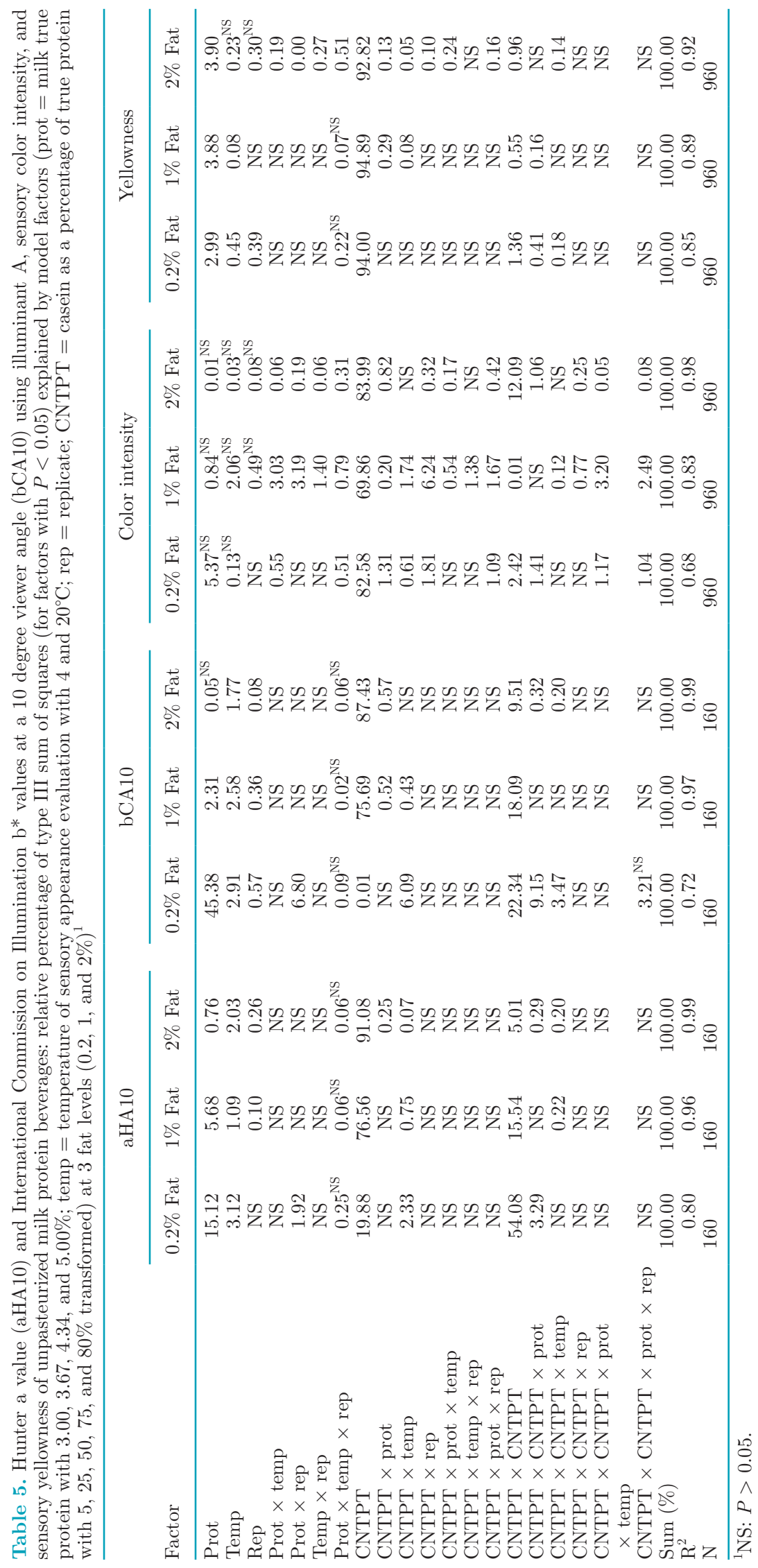


Table 6. Hunter L values at a 10 degree viewer angle (LHA10) using illuminant A, sensory whiteness, sensory opacity, and instrumental viscosity of unpasteurized and homogenized/pasteurized milk protein beverages: relative percentage of type III sum of squares (for factors with $P<0.05$ ) explained by model factors (fat $=$ fat level with $0.2,1$, and $2 \%$ fat; heat $=$ pasteurization and homogenization; prot $=$ milk true protein with 3.00 , $3.67,4.34$, and $5.00 \%$; temp = temperature of sensory appearance evaluation with 4 and $20^{\circ} \mathrm{C}$; rep $=$ replicate; $\mathrm{CNTPT}=$ casein as a percentage of true protein with $5,25,50,75$, and $80 \%$ transformed)

\begin{tabular}{|c|c|c|c|c|}
\hline Factor & LHA10 & Whiteness & Opacity & Viscosity $^{1}$ \\
\hline Fat & 3.97 & 7.40 & 21.88 & 1.13 \\
\hline Heat & 2.58 & 26.93 & 15.98 & 0.08 \\
\hline Prot & 0.23 & 4.47 & 2.25 & 4.24 \\
\hline Temp & 0.18 & $\mathrm{NS}^{2}$ & $0.01^{\mathrm{NS}}$ & 83.85 \\
\hline Rep & NS & NS & NS & 0.46 \\
\hline Fat $\times$ heat & 0.20 & 1.23 & 5.78 & $\mathrm{NS}$ \\
\hline Fat $\times$ prot & 0.35 & 0.42 & 1.11 & NS \\
\hline Fat $\times$ temp & 0.24 & 0.01 & NS & 0.53 \\
\hline Fat $\times$ rep & 0.04 & 0.01 & NS & 1.46 \\
\hline Heat $\times$ prot & 0.09 & 0.62 & 0.03 & NS \\
\hline Heat $\times$ temp & 0.05 & NS & NS & NS \\
\hline Heat $\times$ rep & 0.05 & NS & NS & NS \\
\hline Prot $\times$ temp & NS & NS & 0.02 & NS \\
\hline Prot $\times$ rep & 0.11 & NS & 0.02 & NS \\
\hline Temp $\times$ rep & NS & 0.01 & NS & 0.75 \\
\hline Fat $\times$ heat $\times$ prot & NS & 0.21 & 0.95 & NS \\
\hline Fat $\times$ heat $\times$ temp & 0.04 & NS & 0.03 & NS \\
\hline Fat $\times$ heat $\times$ rep & 0.04 & 0.01 & 0.01 & NS \\
\hline Fat $\times$ prot $\times$ temp & NS & NS & 0.01 & NS \\
\hline Fat $\times$ prot $\times$ rep & 0.18 & 0.02 & 0.02 & NS \\
\hline Heat $\times$ prot $\times$ temp & NS & NS & 0.01 & NS \\
\hline Prot $\times$ temp $\times$ rep & NS & NS & 0.01 & NS \\
\hline Heat $\times$ prot $\times$ rep & NS & 0.01 & 0.01 & NS \\
\hline Fat $\times$ heat $\times$ prot $\times$ tem $p$ & NS & NS & 0.02 & NS \\
\hline Fat $\times$ heat $\times$ prot $\times$ rep & NS & 0.02 & 0.01 & NS \\
\hline Fat $\times$ heat $\times$ prot $\times$ temp $\times$ rep & $0.09^{\mathrm{NS}}$ & 0.04 & 0.07 & 0.47 \\
\hline CNTPT & 43.15 & 44.08 & 36.51 & 3.36 \\
\hline CNTPT $\times$ fat & 8.81 & 0.12 & 2.53 & 0.14 \\
\hline $\mathrm{CNTPT} \times$ heat & 19.26 & 12.47 & 8.89 & 0.11 \\
\hline CNTPT $\times$ prot & NS & 0.01 & NS & 0.27 \\
\hline $\mathrm{CNTPT} \times$ temp & 0.18 & NS & NS & 2.89 \\
\hline $\mathrm{CNTPT} \times$ rep & NS & NS & NS & NS \\
\hline CNTPT $\times$ fat $\times$ heat & 5.36 & 0.03 & 0.07 & NS \\
\hline CNTPT $\times$ heat $\times$ prot & 0.10 & 0.20 & 0.09 & NS \\
\hline CNTPT $\times$ heat $\times$ temp & 0.02 & NS & NS & NS \\
\hline $\mathrm{CNTPT} \times$ heat $\times$ rep & NS & 0.01 & 0.02 & NS \\
\hline CNTPT $\times$ fat $\times$ prot & 0.09 & 0.14 & 0.24 & NS \\
\hline $\mathrm{CNTPT} \times$ fat $\times$ rep & NS & NS & 0.02 & NS \\
\hline CNTPT $\times$ prot $\times$ temp & NS & NS & NS & 0.24 \\
\hline $\mathrm{CNTPT} \times$ temp $\times$ rep & NS & 0.01 & NS & NS \\
\hline CNTPT $\times$ CNTPT & 3.94 & 0.67 & 1.53 & NS \\
\hline $\mathrm{CNTPT} \times \mathrm{CNTPT} \times$ fat & 2.60 & NS & 0.04 & NS \\
\hline $\mathrm{CNTPT} \times \mathrm{CNTPT} \times$ heat & 4.79 & 0.28 & 0.87 & 0.03 \\
\hline $\mathrm{CNTPT} \times \mathrm{CNTPT} \times$ prot & 0.06 & 0.16 & 0.04 & NS \\
\hline $\mathrm{CNTPT} \times \mathrm{CNTPT} \times$ temp & 0.13 & NS & NS & NS \\
\hline $\mathrm{CNTPT} \times \mathrm{CNTPT} \times$ fat $\times$ heat & 2.72 & 0.04 & 0.59 & NS \\
\hline $\mathrm{CNTPT} \times \mathrm{CNTPT} \times$ fat $\times$ prot & 0.09 & 0.08 & 0.25 & NS \\
\hline $\mathrm{CNTPT} \times \mathrm{CNTPT} \times$ fat $\times$ temp & 0.03 & 0.01 & NS & NS \\
\hline $\mathrm{CNTPT} \times \mathrm{CNTPT} \times$ heat $\times$ prot & 0.13 & 0.29 & 0.02 & NS \\
\hline $\mathrm{CNTPT} \times \mathrm{CNTPT} \times$ heat $\times$ temp & 0.07 & NS & NS & NS \\
\hline $\mathrm{CNTPT} \times \mathrm{CNTPT} \times$ prot $\times$ temp & NS & NS & 0.02 & NS \\
\hline $\mathrm{CNTPT} \times \mathrm{CNTPT} \times$ temp $\times$ rep & NS & NS & NS & NS \\
\hline $\mathrm{CNTPT} \times \mathrm{CNTPT} \times$ prot $\times$ rep & 0.04 & NS & 0.01 & NS \\
\hline $\operatorname{Sum}(\%)$ & 100.00 & 100.00 & 100.00 & 100.00 \\
\hline $\mathrm{R}^{2}$ & 0.99 & 0.98 & 0.98 & 0.94 \\
\hline $\mathrm{N}$ & 960 & 5,760 & 5,760 & 1,440 \\
\hline
\end{tabular}

${ }^{1}$ Instrumental viscosity included data from 4,20 , and $50^{\circ}$.

${ }^{2}$ NS: $P>0.05$. 
Table 7. Hunter a (aHA10) and International Commission on Illumination $\mathrm{b}^{*}$ values at a 10 degree viewer angle (bCA10) using illuminant A, sensory color intensity, and sensory yellowness of unpasteurized and homogenized/pasteurized milk protein beverages: relative percentage of type III sum of squares explained by model factors (fat $=$ fat level with $0.2,1$, and $2 \%$ fat; heat $=$ pasteurization and homogenization; prot $=$ milk true protein with $3.00,3.67,4.34$, and $5.00 \%$; temp = temperature of sensory appearance evaluation with 4 and $20^{\circ} \mathrm{C}$; rep $=$ replicate; $\mathrm{CNTPT}=$ casein as a percentage of true protein with $5,25,50,75$, and $80 \%$ transformed $)^{1}$

\begin{tabular}{|c|c|c|c|c|}
\hline Factor & aHA10 & bCA10 & Color intensity & Yellowness \\
\hline Fat & 54.72 & 38.09 & 11.64 & 0.14 \\
\hline Heat & 4.96 & 5.28 & 1.44 & 31.88 \\
\hline Prot & 1.85 & 1.59 & 0.35 & 1.09 \\
\hline Temp & 0.13 & 0.18 & $0.01^{\mathrm{NS}}$ & 0.06 \\
\hline Rep & 0.02 & 0.02 & $0.03^{\mathrm{NS}}$ & $0.01^{\mathrm{NS}}$ \\
\hline Fat $\times$ heat & 0.57 & 2.29 & 0.63 & 9.45 \\
\hline Fat $\times$ prot & 1.81 & 1.67 & 0.48 & 0.50 \\
\hline Fat $\times$ temp & 1.15 & 0.49 & 0.40 & NS \\
\hline Fat $\times$ rep & NS & 0.25 & 0.42 & 0.02 \\
\hline Heat $\times$ prot & 0.07 & 0.16 & 0.12 & 0.67 \\
\hline Heat $\times$ temp & NS & NS & 0.11 & 0.06 \\
\hline Heat $\times$ rep & NS & NS & 0.09 & 0.03 \\
\hline Prot $\times$ temp & NS & NS & 0.06 & 0.03 \\
\hline Prot $\times$ rep & 0.12 & 0.09 & 0.14 & 0.03 \\
\hline Fat $\times$ heat $\times$ prot & 0.17 & 0.12 & 1.07 & 0.36 \\
\hline Fat $\times$ heat $\times$ temp & 0.08 & 0.16 & 0.39 & NS \\
\hline Fat $\times$ heat $\times$ rep & NS & NS & 1.01 & 0.07 \\
\hline Fat $\times$ prot $\times$ temp & NS & NS & 0.11 & 0.04 \\
\hline Fat $\times$ prot $\times$ rep & 0.37 & 0.26 & 0.18 & 0.08 \\
\hline Fat $\times$ temp $\times$ rep & NS & NS & 0.15 & NS \\
\hline Heat $\times$ prot $\times$ temp & NS & NS & 0.10 & NS \\
\hline Heat $\times$ prot $\times$ rep & NS & NS & 0.25 & 0.03 \\
\hline Heat $\times$ temp $\times$ rep & NS & NS & 0.06 & 0.03 \\
\hline Fat $\times$ heat $\times$ prot $\times$ temp & NS & NS & 0.19 & NS \\
\hline Fat $\times$ heat $\times$ prot $\times$ rep & NS & NS & 0.14 & 0.05 \\
\hline Fat $\times$ prot $\times$ temp $\times$ rep & NS & NS & 0.26 & 0.05 \\
\hline Fat $\times$ heat $\times$ temp $\times$ rep & NS & NS & 0.15 & 0.05 \\
\hline Heat $\times$ prot $\times$ temp $\times$ rep & NS & NS & 0.13 & 0.04 \\
\hline Fat $\times$ heat $\times$ prot $\times$ temp $\times$ rep & $0.12^{\mathrm{NS}}$ & $0.10^{\mathrm{NS}}$ & 0.12 & $0.05^{\mathrm{NS}}$ \\
\hline CNTPT & 18.13 & 24.92 & 46.97 & 46.19 \\
\hline $\mathrm{CNTPT} \times$ fat & 0.70 & 4.86 & 10.33 & NS \\
\hline CNTPT $\times$ heat & 3.85 & 3.11 & 12.01 & 7.23 \\
\hline CNTPT $\times$ prot & 0.12 & 0.38 & 0.24 & 0.04 \\
\hline $\mathrm{CNTPT} \times$ temp & 0.28 & 0.18 & 0.15 & NS \\
\hline CNTPT $\times$ rep & NS & NS & 0.02 & 0.02 \\
\hline CNTPT $\times$ fat $\times$ heat & 0.58 & 6.48 & 0.31 & 0.79 \\
\hline CNTPT $\times$ heat $\times$ prot & 0.16 & NS & 0.21 & NS \\
\hline $\mathrm{CNTPT} \times$ heat $\times$ temp & NS & 0.17 & 0.15 & 0.02 \\
\hline CNTPT $\times$ heat $\times$ rep & NS & NS & 0.63 & NS \\
\hline CNTPT $\times$ fat $\times$ temp & 0.23 & 0.25 & 0.15 & 0.03 \\
\hline CNTPT $\times$ fat $\times$ prot & NS & NS & 0.23 & 0.13 \\
\hline $\mathrm{CNTPT} \times$ fat $\times$ rep & NS & NS & 0.76 & NS \\
\hline $\mathrm{CNTPT} \times$ prot $\times$ temp & NS & NS & 0.08 & NS \\
\hline CNTPT $\times$ temp $\times$ rep & NS & NS & 0.02 & NS \\
\hline $\mathrm{CNTPT} \times$ prot $\times$ rep & NS & 0.08 & 0.20 & NS \\
\hline $\mathrm{CNTPT} \times \mathrm{CNTPT}$ & 2.59 & 1.31 & 0.63 & 0.37 \\
\hline $\mathrm{CNTPT} \times \mathrm{CNTPT} \times$ fat & 0.64 & 0.50 & 0.87 & NS \\
\hline $\mathrm{CNTPT} \times \mathrm{CNTPT} \times$ heat & 5.01 & 6.49 & 2.30 & 0.11 \\
\hline $\mathrm{CNTPT} \times \mathrm{CNTPT} \times$ prot & NS & 0.07 & 0.09 & 0.06 \\
\hline $\mathrm{CNTPT} \times \mathrm{CNTPT} \times$ temp & NS & NS & NS & 0.05 \\
\hline $\mathrm{CNTPT} \times \mathrm{CNTPT} \times$ rep & NS & NS & 0.06 & NS \\
\hline $\mathrm{CNTPT} \times \mathrm{CNTPT} \times$ fat $\times$ heat & 1.46 & 0.10 & 2.40 & NS \\
\hline $\mathrm{CNTPT} \times \mathrm{CNTPT} \times$ fat $\times$ prot & NS & 0.11 & 0.40 & NS \\
\hline $\mathrm{CNTPT} \times \mathrm{CNTPT} \times$ fat $\times$ temp & NS & 0.17 & NS & NS \\
\hline $\mathrm{CNTPT} \times \mathrm{CNTPT} \times$ fat $\times$ rep & NS & NS & 0.03 & 0.05 \\
\hline $\mathrm{CNTPT} \times \mathrm{CNTPT} \times$ heat $\times$ prot & 0.13 & 0.09 & 0.19 & NS \\
\hline CNTPT $\times$ CNTPT $\times$ heat $\times$ rep & NS & NS & 0.14 & 0.03 \\
\hline $\mathrm{CNTPT} \times \mathrm{CNTPT} \times \operatorname{prot} \times$ temp & NS & NS & 0.07 & NS \\
\hline $\mathrm{CNTPT} \times \mathrm{CNTPT} \times$ prot $\times$ rep & NS & NS & 0.13 & 0.02 \\
\hline Sum $(\%)$ & 100.00 & 100.00 & 100.00 & 100.00 \\
\hline $\mathrm{R}^{2}$ & 0.97 & 0.97 & 0.88 & 0.90 \\
\hline $\mathrm{N}$ & 960 & 960 & 5,760 & 5,760 \\
\hline
\end{tabular}

${ }^{1} \mathrm{NS}: P>0.05$. 
having lower $\mathrm{b}^{*}$ values (Figure $2 \mathrm{~B}$ ). Heat, CNTPT $\times$ heat, and $\mathrm{CNTPT} \times \mathrm{CNTPT} \times$ heat, fat $\times$ heat, and CNTPT $\times$ fat $\times$ heat contributed to $5.28,3.11$, and $6.49 \%$, and 2.29 and $6.48 \%$, in total $23.65 \%$ of the total variation of $b^{*}$ values (Table 7 ). Heat treatment decreased the $\mathrm{b}^{*}$ values in the 5 to $25 \%$ range of $\mathrm{CN} \% \mathrm{TP}$ for the 1 and $2 \%$ fat beverages, whereas it showed little effect on $b^{*}$ values in the $0.2 \%$ fat products and higher range of $\mathrm{CN} \% \mathrm{TP}$ for the 1 and $2 \%$ fat beverages (Figure $2 \mathrm{~B}$ ).

Color Intensity. Variation in fat, CNTPT, CNTPT $\times$ fat, and CNTPT $\times$ heat, explained $81 \%$ of the total variation of color intensity, with CNTPT having the largest effect (Table 7). Heat treatment decreased the color intensity of the 1 and $2 \%$ products more than the skim products in the lower CN\% TP range (Figure 2C).

Sensory Yellowness. Variation in heat, fat $\times$ heat, CNTPT, and CNTPT $\times$ heat explained $94.75 \%$ of the total variation of color intensity, with CNTPT and heat having the largest effects (Table 7). Heat treatment plus homogenization decreased the yellowness more in the higher fat level products than in low fat products (Figure 2D). Overall, heat (pasteurization and homogenization) decreased sensory color intensity and sensory yellowness (Figures 2C and D). Changes in a and $\mathrm{b}^{*}$ values with increasing $\mathrm{CN} \% \mathrm{TP}$ were more complex (Figures 2A and B).

Heat (pasteurization plus homogenization) caused more light of all wavelengths to be reflected back from the surface of milk protein beverages and increased L values (Figure 1A) and sensory whiteness (Figure 1B). After pasteurization plus homogenization, the amount of light that penetrated into the serum phase and into the fat globules decreased (more casein micelles surround the fat globule) more than the light absorbed by the serum phase soluble compounds (such as riboflavin for a values) and fat soluble compounds (such as carotenoids for b* values) increased (Misawa et al., 2016), resulting in overall decreases in sensory color intensity and sensory yellowness (Figures 2C and D). However, overall fat concentration had a greater effect on a and $\mathrm{b}^{*}$ values than heat (pasteurization plus homogenization; Table 7, Figures 2A and B) and CNTPT plus the interactions of CNTPT with fat and heat (Table 7) had a greater effect on sensory color intensity and sensory yellowness than both fat and pasteurization plus homogenization.

Instrumental Viscosity. Heat (i.e., pasteurized versus unpasteurized) and heat-related terms explained $<0.25 \%$ of the total variation of instrumental viscosity across fat levels, whereas temperature (i.e., temperature of measurement of viscosity) explained $83.85 \%$ of the variation in measured viscosity (Table 6 ). When measuring the viscosity of these beverages at $4^{\circ} \mathrm{C}$, the effects of CNTPT, protein, CNTPT $\times$ protein, and fat explained $65.35,16.19,5.55$, and $4.54 \%$ of the total variation of instrumental viscosity, respectively, with a $\mathrm{R}^{2}$ value of 0.96 (Table 8). Variation in protein, CNTPT, and fat explained 48.85, 27.50, and $10.94 \%$ of the total variation of instrumental viscosity, respectively, when testing at $20^{\circ} \mathrm{C}$ with a higher $\mathrm{R}^{2}$ value of 0.88 for the model, while they contributed to 35.44 , 7.96 , and $16.95 \%$ of the total variation of instrumental viscosity at $50^{\circ} \mathrm{C}$ with a lower $\mathrm{R}^{2}$ value of 0.68 for the model (Table 8 ). When the $\mathrm{R}^{2}$ value for the model was low (such as at $50^{\circ} \mathrm{C}$ ), the model had a more difficult time separating the effect of the effect of variation in protein concentration, $\mathrm{CN} \% \mathrm{TP}$, and fat on instrumental viscosity value. Increasing testing temperature from 4 to $50^{\circ} \mathrm{C}$ decreased instrumental viscosity and masked the viscosity changes caused by composition differences within the formulas (Figure 3). Increases in CN\%TP increased viscosity more than increases in protein did, when measuring at $4^{\circ} \mathrm{C}$ (Table 8 and Figure 4), whereas the effects of changes in protein and $\mathrm{CN} \% \mathrm{TP}$ at 20 and $50^{\circ} \mathrm{C}$ were small (data not shown). Increases in $\mathrm{CN} \% \mathrm{TP}$ and $\mathrm{CN}$ concentration were reported to increase the relative viscosity of milk protein beverages (Misawa et al., 2016). Temperature-dependent disassociation of $\beta$-casein out of micelles at $4^{\circ} \mathrm{C}$ increased the protein concentration in the serum phase and may have increased the viscosity for the milk protein beverages.

\section{Prediction of Sensory Whiteness and Yellowness with Instrumental Color Measures}

Preliminary PCA runs for the sensory whiteness data and the sensory yellowness data (biplots not shown) indicated that all the 5\% CNTP formulations were a different cluster of formulations due to the nonlinear changes in color with the change in CN\% TP (Tables 4 and 5; Figures 1 and 2). Removal of the $5 \% \mathrm{CN} \% \mathrm{TP}$ formulations also caused major changes in the PCA vectors and their interrelationships for the subpopulation of formulations, with principal component 1 explaining most of the variation in sensory whiteness and yellowness. Once the 5\% CNTP formulations were removed from the population and new biplots were constructed with skim, 1 and $2 \%$ formulations together as one population (not shown), it was determined that the skim unpasteurized beverages were clustered separately from the unpasteurized 1 and $2 \%$ fat beverages with respect to whiteness. Separate PCA plots were done for whiteness of skim (Figure 5) and 1 plus $2 \%$ fat beverages (Figure 6), which represented more homogeneous subpopulations of beverage population (with most of 
Table 8. Instrumental viscosity of milk protein beverages: relative percentage of type III sum of squares explained by model factors (fat $=$ fat level with $0.2,1$, and $2 \%$ fat; heat $=$ pasteurization and homogenization; prot $=$ milk true protein with $3.00,3.67,4.34$, and $5.00 \%$; temp $=$ temperature of sensory appearance evaluation with 4 and $20^{\circ} \mathrm{C}$; rep = replicate; $\mathrm{CNTPT}=$ casein as a percentage of true protein with $5,25,50,75$, and $80 \%$ transformed) at 3 measurement temperatures $\left(4,20 \text {, and } 50^{\circ} \mathrm{C}\right)^{1}$

\begin{tabular}{|c|c|c|c|}
\hline \multirow[b]{2}{*}{ Factor } & \multicolumn{3}{|c|}{ Viscosity } \\
\hline & $4^{\circ} \mathrm{C}$ & $20^{\circ} \mathrm{C}$ & $50^{\circ} \mathrm{C}$ \\
\hline Fat & 4.54 & 10.94 & 16.95 \\
\hline Heat & 0.56 & 1.92 & $0.54^{\mathrm{NS}}$ \\
\hline Prot & 16.19 & 48.85 & 35.44 \\
\hline Rep & 0.08 & 0.77 & $0.09^{\mathrm{NS}}$ \\
\hline Fat $\times$ heat & NS & 0.95 & NS \\
\hline Fat $\times$ prot & 0.94 & NS & NS \\
\hline Fat $\times$ rep & 0.61 & NS & NS \\
\hline Heat $\times$ prot & 0.43 & 0.35 & 3.69 \\
\hline Heat $\times$ rep & NS & $0.03^{\mathrm{NS}}$ & 5.09 \\
\hline Prot $\times$ rep & 0.53 & 0.37 & 1.55 \\
\hline Fat $\times$ heat $\times$ rep & NS & 0.33 & 5.17 \\
\hline Fat $\times$ prot $\times$ rep & 0.74 & 1.15 & 6.66 \\
\hline Heat $\times$ prot $\times$ rep & NS & $0.20^{\mathrm{NS}}$ & $1.47^{\mathrm{NS}}$ \\
\hline Fat $\times$ heat $\times$ prot $\times$ rep & $0.27^{\mathrm{NS}}$ & $0.34^{\mathrm{NS}}$ & 4.93 \\
\hline CNTPT & 65.35 & 27.50 & 7.96 \\
\hline CNTPT $\times$ fat & 1.70 & 1.47 & 2.69 \\
\hline CNTPT $\times$ heat & 1.19 & 1.62 & NS \\
\hline CNTPT $\times$ prot & 5.55 & 2.33 & NS \\
\hline $\mathrm{CNTPT} \times$ heat $\times$ prot & 0.18 & NS & NS \\
\hline $\mathrm{CNTPT} \times$ fat $\times$ prot & NS & NS & 5.06 \\
\hline CNTPT $\times$ fat $\times$ rep & 0.12 & NS & NS \\
\hline CNTPT $\times$ prot $\times$ rep & 0.15 & NS & NS \\
\hline $\mathrm{CNTPT} \times \mathrm{CNTPT}$ & 0.08 & $0.04^{\mathrm{NS}}$ & NS \\
\hline $\mathrm{CNTPT} \times \mathrm{CNTPT} \times$ fat & 0.12 & NS & NS \\
\hline $\mathrm{CNTPT} \times \mathrm{CNTPT} \times$ heat & 0.27 & 0.85 & NS \\
\hline $\mathrm{CNTPT} \times \mathrm{CNTPT} \times$ prot & 0.20 & NS & NS \\
\hline $\mathrm{CNTPT} \times \mathrm{CNTPT} \times$ heat $\times$ prot & NS & NS & 2.72 \\
\hline $\mathrm{CNTPT} \times \mathrm{CNTPT} \times$ prot $\times$ rep & 0.19 & NS & NS \\
\hline Sum $(\%)$ & 100.00 & 100.00 & 100.00 \\
\hline $\mathrm{R}^{2}$ & 0.96 & 0.88 & 0.68 \\
\hline $\mathrm{N}$ & 480 & 480 & 480 \\
\hline
\end{tabular}

${ }^{1} \mathrm{NS}: P>0.05$.

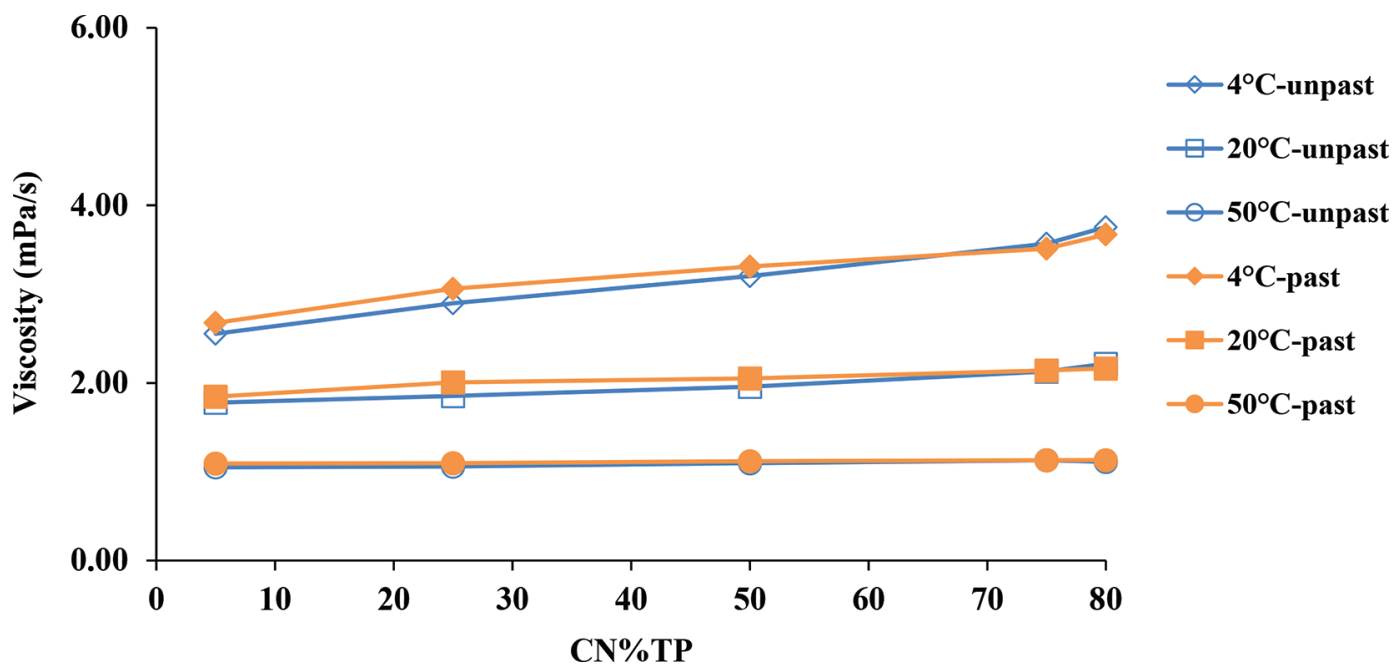

Figure 3. Instrumental viscosity for unpasteurized (unpast) and pasteurized (past) milk protein beverages with different temperatures (4, 20 , and $50^{\circ} \mathrm{C}$ ) as a function of casein as a percentage of true protein $(\mathrm{CN} \% \mathrm{TP})$. 

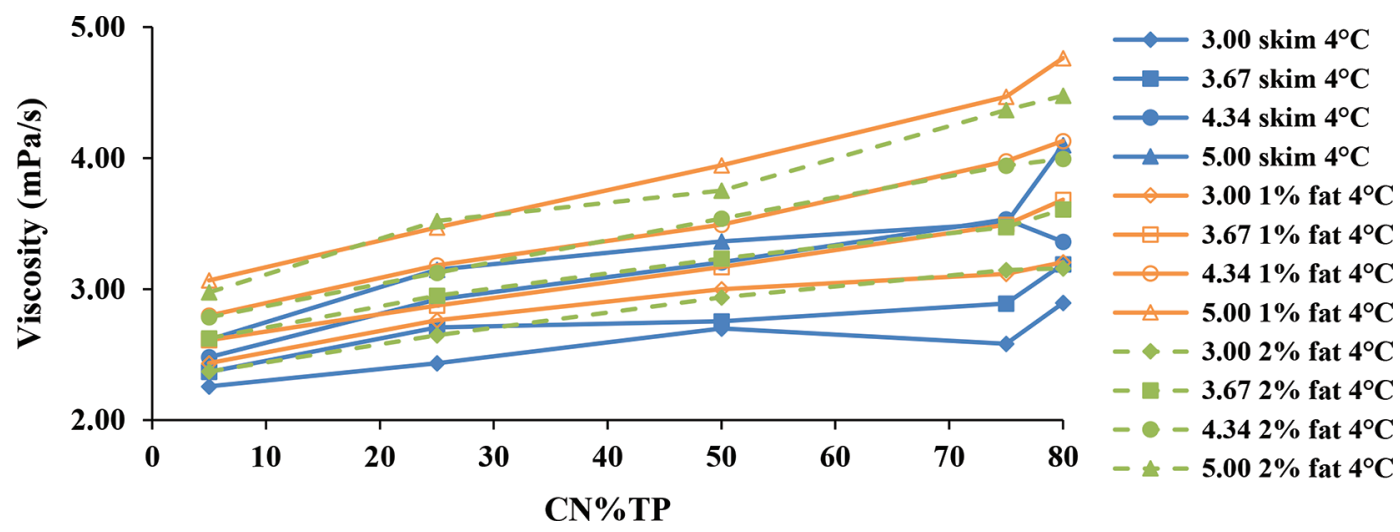

Figure 4. Instrumental viscosity for milk protein beverages with different true protein levels $(3.00,3.67,4.34$, and $5.00 \%)$ as a function of casein as a percentage of true protein $(\mathrm{CN} \% \mathrm{TP})$ at $4^{\circ} \mathrm{C}$.

the variation explained by principal component 1 for prediction of sensory whiteness from instrumental color measurements. When only one principal component explains most of the variation in sensory whiteness and the vectors for whiteness opacity and $\mathrm{L}$ values are of similar magnitude and direction (Figures 5 and 6), it is likely that $\mathrm{L}$ values alone may be a reasonably good predictor of sensory whiteness.

\section{- Active variables • Active observations}

\section{Biplot (axes F1 and F2: 99.2\%)}

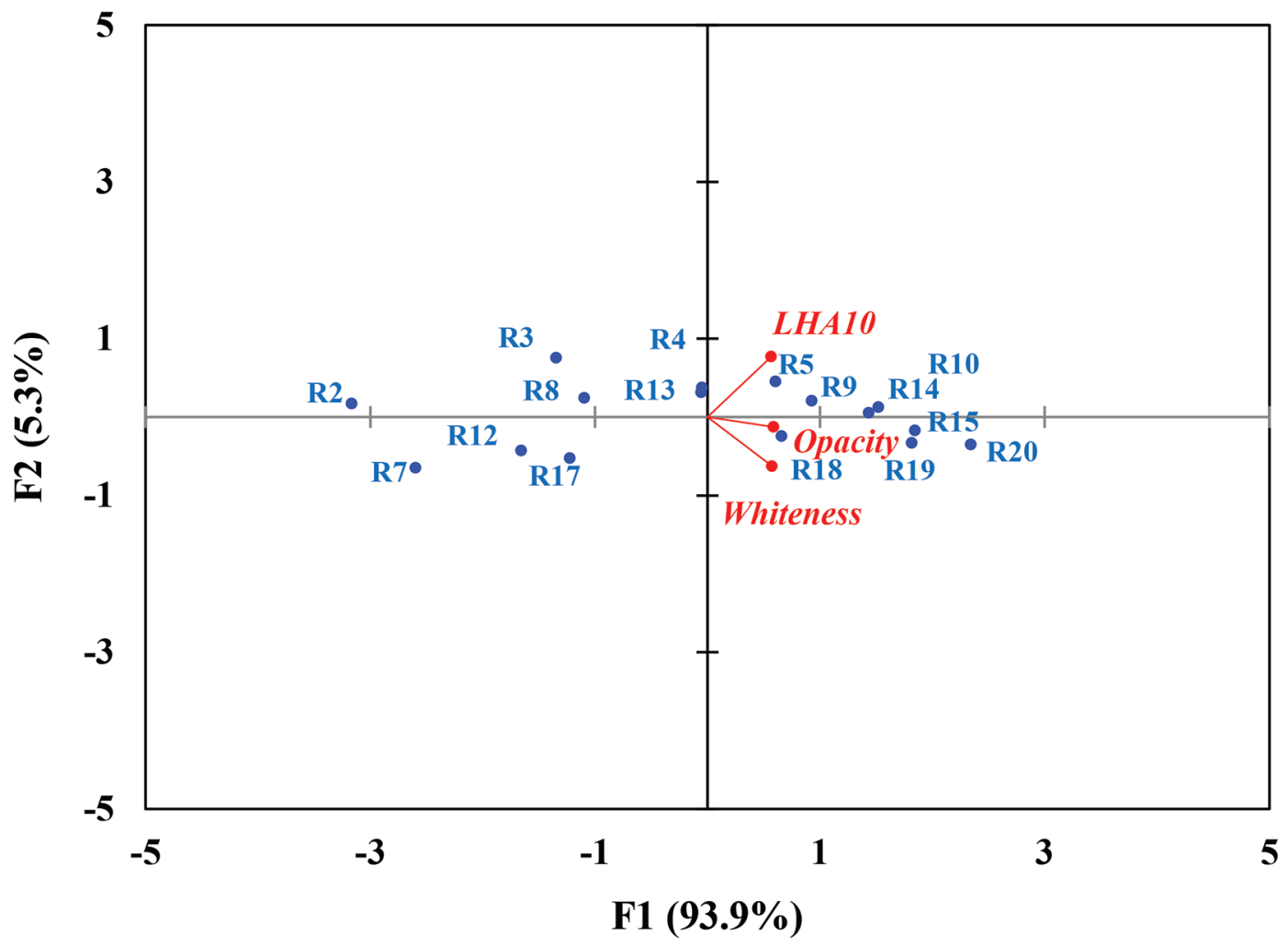

Figure 5. Principal component analysis biplot for Hunter L values at 10 degree viewer angle (LHA10), sensory whiteness and sensory opacity of unpasteurized skim beverages with removing 4 beverages with $5 \%$ casein as a percentage of true protein. "R" represents unpasteurized. The number next to each letter represents a specific formula in Table 1. 
MILK PROTEIN BEVERAGES

\section{- Active variables - Active observations}

\section{Biplot (axes F1 and F2: 95.8\%)}

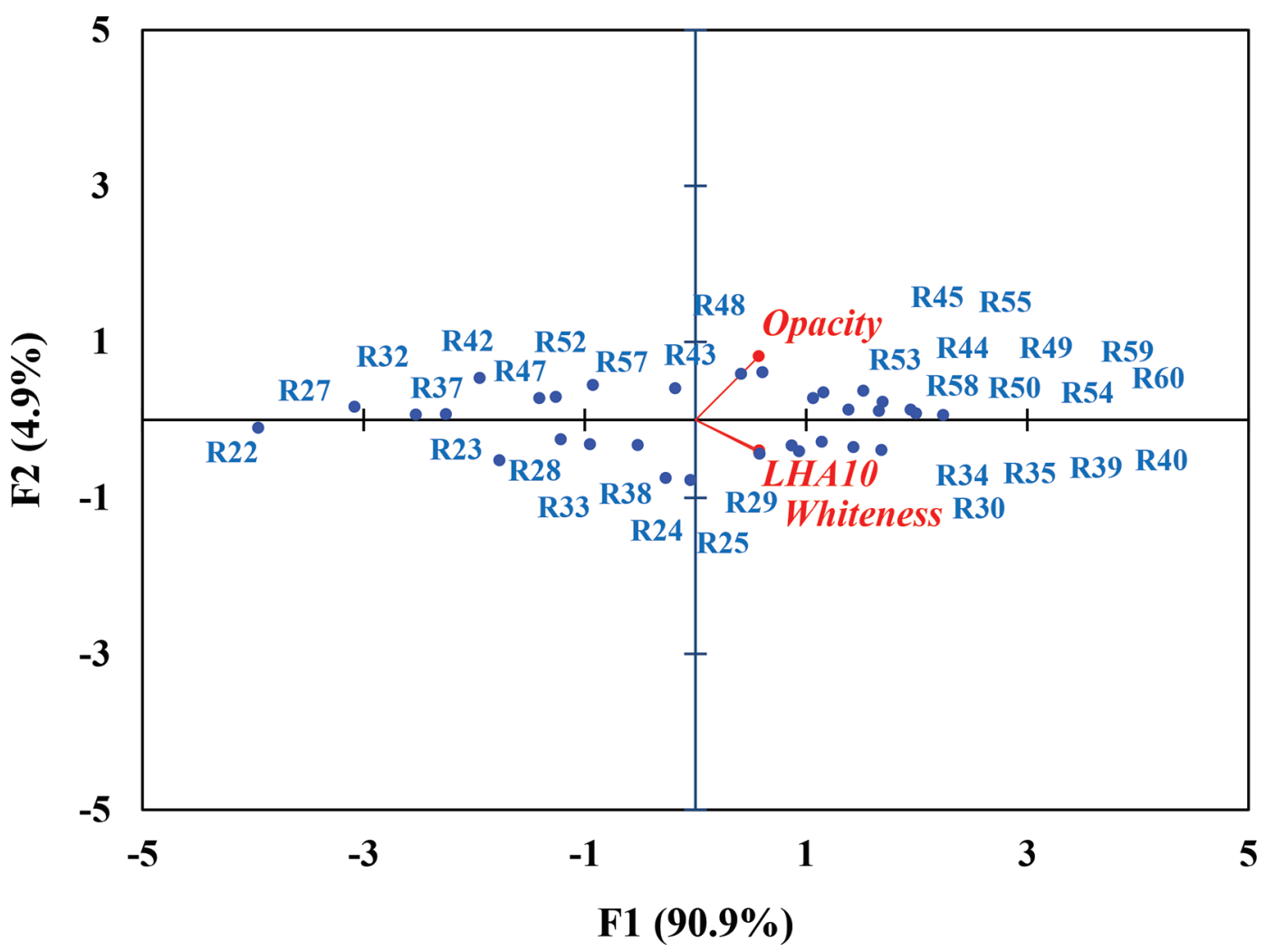

Figure 6. Principal component analysis biplot for Hunter L values at 10 degree viewer angle (LHA10), sensory whiteness and sensory opacity of unpasteurized 1 and $2 \%$ fat beverages with removing 8 beverages with $5 \%$ casein as a percentage of true protein. "R" represents unpasteurized. The number next to each letter represents a specific formula in Table 1.

Similar PCA biplots were made for skim yellowness (Figure 7) and 1 plus 2\% fat beverage (Figure 8) yellowness. In these PCA biplots, the vector for sensory yellowness and $\mathrm{b}^{*}$ value do not project in the same direction for skim (Figure 7) or for 1 plus $2 \%$ fat (Figure 8). In addition, the relationship of the vectors to principal components 1 and 2 are different in skim (Figure 7 ) versus 1 plus $2 \%$ fat (Figure 8 ). It is possible

Table 9. Linear, quadratic, and multiple linear regression statistic summary by using Hunter L, a, and International Commission on Illumination $\mathrm{b}^{*}$ values at 10 degree viewer angles (LHA10, aHA10, and bCA10) as indicators to predict sensory whiteness for unpasteurized skim, and 1 and $2 \%$ fat milk protein beverages with excluding beverages of $5 \%$ casein as a percentage of true protein

\begin{tabular}{|c|c|c|c|c|c|c|}
\hline \multirow[b]{3}{*}{ Item } & \multicolumn{3}{|c|}{$0.2 \%$ Fat } & \multicolumn{3}{|c|}{1 and $2 \%$ Fat } \\
\hline & \multicolumn{2}{|c|}{$\begin{array}{c}\text { LHA10/sensory } \\
\text { whiteness }\end{array}$} & \multirow{2}{*}{$\begin{array}{c}\begin{array}{c}\text { LHA10, aHA10 and } \\
\text { bCA10/sensory } \\
\text { whiteness }\end{array} \\
\text { Multiple linear }\end{array}$} & \multicolumn{2}{|c|}{$\begin{array}{c}\text { LHA10/sensory } \\
\text { whiteness }\end{array}$} & \multirow{2}{*}{$\begin{array}{c}\text { LHA10, aHA10, and } \\
\text { bCA10/sensory } \\
\text { whiteness }\end{array}$} \\
\hline & Linear & Quadratic & & Linear & Quadratic & \\
\hline Multiple R & 0.8455 & & 0.9194 & 0.8738 & & 0.9311 \\
\hline $\mathrm{SE}$ & 0.7091 & & 0.5641 & 0.5811 & & 0.4510 \\
\hline Observations & 16 & 16 & 16 & 32 & 32 & 32 \\
\hline
\end{tabular}


that there may be a more complex relationship between instrumental measures of color and sensory color perception for yellowness. This approach was designed to select subpopulations of beverages to achieve better predictive power for the instrumental whiteness and yellowness that will match sensory.

Regression statistics of linear, quadratic, and MLR for the whiteness group ( $\mathrm{L}$ values, or $\mathrm{L}, \mathrm{a}$, and $\mathrm{b}^{*}$ values) and for the yellowness group ( $\mathrm{b}^{*}$ values or $\mathrm{L}$, a, and $\mathrm{b}^{*}$ values) are summarized in Tables 9 and 10, respectively. The higher the $\mathrm{R}^{2}$ that a model has, the better the fit or prediction. Using the $\mathrm{L}$ values, the linear regression prediction of sensory whiteness produced a $\mathrm{R}^{2}$ of 0.71 for the skim beverages and 0.76 for the 1 and $2 \%$ fat beverages and the quadratic regression prediction of sensory whiteness had an $\mathrm{R}^{2}$ of 0.77 for the skim beverages and 0.80 for the 1 and $2 \%$ fat beverages (Table 9). Other researchers have found that Hunter L or CIE L* values had a higher correlation with sensory whiteness or lightness of milk chocolate (Guinard and Mazzucchelli, 1999) and dairy desserts (Tárrega and Costell, 2007) by using a single instrumental parameter for the prediction of whiteness/lightness. The MLR was used in the current study to generate a more powerful prediction model for sensory whiteness of unpasteurized milk protein beverages than linear or quadratic regression. The MLR prediction for sensory whiteness, including $\mathrm{L}, \mathrm{a}$, and $\mathrm{b}^{*}$ values, produced a higher $\mathrm{R}^{2}$ (0.84 for skim beverages and 0.87 for 1 and $2 \%$ fat beverages) than the linear and quadratic regression predictions (Table 9). Only using the $b^{*}$ values, the linear regression prediction of sensory yellowness showed a low $\mathrm{R}^{2}(0.02)$ for the skim beverages and 0.6347 for the 1 and $2 \%$ fat beverages and the quadratic regression prediction of sensory yellowness had a $\mathrm{R}^{2}$ of 0.005 for the skim beverages and 0.65 for the 1 and $2 \%$ fat bever-

\section{- Active variables • Active observations}

\section{Biplot (axes F1 and F2: 94.2\%)}

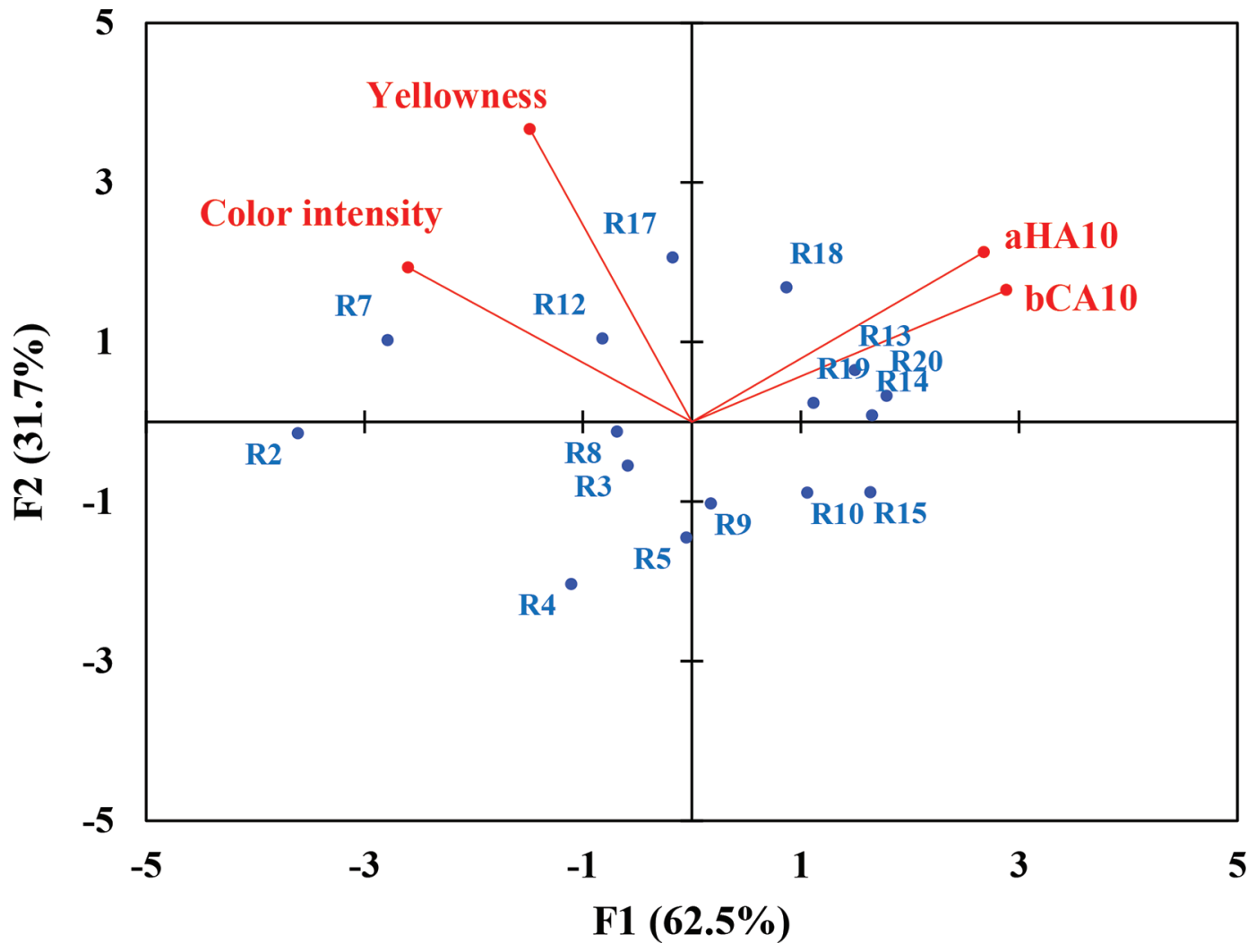

Figure 7. Principal component analysis biplot for Hunter a and International Commission on Illumination b* values at 10 degree viewer angle (aHA10 and bCA10), sensory color intensity, and sensory yellowness of unpasteurized skim beverages with removing 4 beverages with $5 \%$ casein as a percentage of true protein. "R" represents unpasteurized. The number next to each letter represents a specific formula in Table 1. 
- Active variables - Active observations

Biplot (axes F1 and F2: 96.9\%)

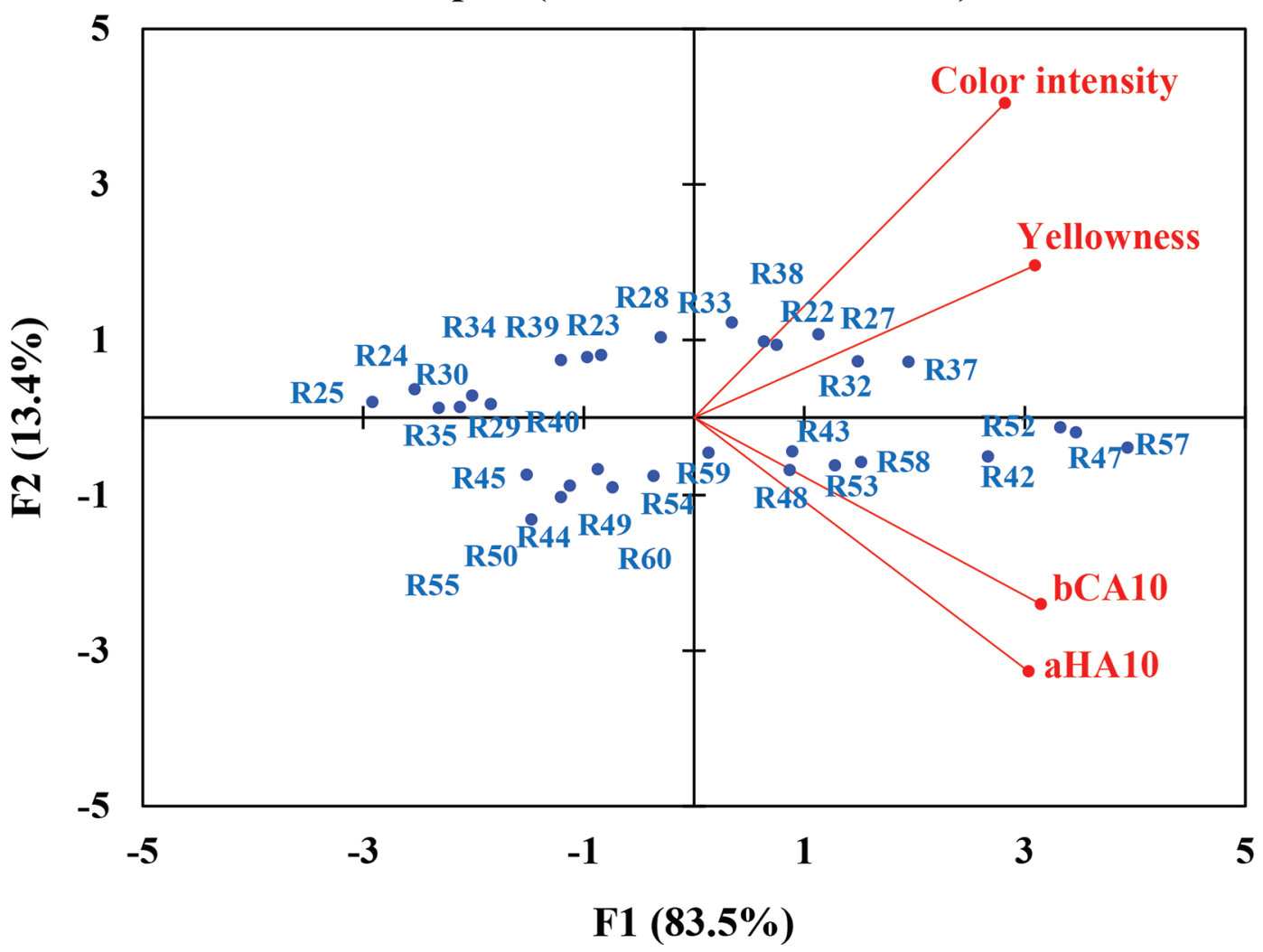

Figure 8. Principal component analysis biplot for Hunter a and International Commission on Illumination b* values at 10 degree viewer angle (aHA10 and bCA10), sensory color intensity, and sensory yellowness of unpasteurized 1 and $2 \%$ beverages with removing 8 beverages with $5 \%$ casein as a percentage of true protein. " $\mathrm{R}$ " represents unpasteurized. The number next to each letter represents a specific formula in Table 1.

ages (Table 10). These lower $\mathrm{R}^{2}$ values for linear regression b values and sensory yellowness (Table 10) versus the higher values for $\mathrm{L}$ value and sensory whiteness (Table 9) were consistent with the visual relationships in the PCA biplots for L values and sensory whiteness
(Figures 5 and 6), whereas for sensory yellowness and $b^{*}$ values there were no visual relationships (Figures 7 and 8). This is in agreement with results from Misawa et al. (2016) that the instrumental $b^{*}$ value and sensory yellowness of milk protein beverages were different.

Table 10. Linear, quadratic, and multiple linear regression statistic summary by using Hunter L, a, and International Commission on Illumination $\mathrm{b}^{*}$ values at 10 degree viewer angles (LHA10, aHA10, and bCA10) as indicators to predict sensory yellowness for unpasteurized skim, and 1 and $2 \%$ fat milk protein beverages with excluding beverages of $5 \%$ casein as a percentage of true protein

\begin{tabular}{|c|c|c|c|c|c|c|}
\hline \multirow[b]{3}{*}{ Item } & \multicolumn{3}{|c|}{$0.2 \%$ Fat } & \multicolumn{3}{|c|}{1 and $2 \%$ Fat } \\
\hline & \multicolumn{2}{|c|}{$\begin{array}{c}\text { bCA10/sensory } \\
\text { yellowness }\end{array}$} & \multirow{2}{*}{$\begin{array}{c}\begin{array}{c}\text { LHA10, aHA10 and } \\
\text { bCA10/sensory } \\
\text { yellowness }\end{array} \\
\text { Multiple linear }\end{array}$} & \multicolumn{2}{|c|}{$\begin{array}{c}\text { bCA10/sensory } \\
\text { yellowness }\end{array}$} & \multirow{2}{*}{$\begin{array}{c}\begin{array}{c}\text { LHA10, aHA10, and } \\
\text { bCA10/sensory } \\
\text { yellowness }\end{array} \\
\text { Multiple linear }\end{array}$} \\
\hline & Linear & Quadratic & & Linear & Quadratic & \\
\hline Multiple R & 0.1270 & & 0.9612 & 0.7967 & & 0.9173 \\
\hline SE & 0.5446 & & 0.1637 & 0.3676 & & 0.2506 \\
\hline Observations & 16 & & 16 & 32 & & 32 \\
\hline
\end{tabular}


Thus, MLR prediction for sensory yellowness used L, $\mathrm{a}$, and $\mathrm{b}^{*}$ values, produced a much higher $\mathrm{R}^{2}$ with 0.92 and 0.84 for skim, $1 \%$ fat, and $2 \%$ fat beverages, respectively (Table 10) than linear or polynomial regression. The MLR using L, a, and $b^{*}$ values together generated a more robust prediction of sensory whiteness and sensory yellowness of the unpasteurized milk protein beverages than using a single instrumental parameter ( $\mathrm{L}$ or $\mathrm{b}^{*}$ values), and this may be a useful approach for using instrumental color measurements for quality control testing and for control of the consistency of color of milk-based beverages in a beverage manufacturing plant. Instrumental predictions of sensory color may be useful for exploring beverage reformulation with different ingredients to control raw material cost while determining if the formulation change is likely to cause a perceived difference in sensory properties of the beverage by consumers.

\section{CONCLUSIONS}

For unpasteurized milk protein beverages across 3 fat levels $(0.2,1$, and $2 \%$ ), change in CN\% TP had the largest effect on L values, sensory whiteness, opacity, color intensity, and yellowness, whereas changes in fat concentration had a stronger influence on a and $b^{*}$ values. Increasing in CN\%TP from 5 to $80 \%$ increased L values, sensory whiteness, and opacity, and decreased sensory color intensity and yellowness. The a and $b^{*}$ values increased with increasing fat concentration. For unpasteurized milk protein beverages within each fat level, the effect of variation in $\mathrm{CN} \% \mathrm{TP}$ dominated the changes in L values, sensory whiteness, and opacity, and decreased $\mathrm{a}$ and $\mathrm{b}^{*}$ values, sensory color intensity, and yellowness. The effect of heat (pasteurization and homogenization) and its interaction terms were the second largest effect on color of milk protein beverages with respect to instrumental color data and sensory appearance attributes. Heat increased L values, sensory whiteness, and opacity, and decreased $a$ and $b^{*}$ values, sensory color intensity, and yellowness. Increases in temperature dramatically decreased instrumental viscosity and changes in protein concentration and CN\%TP had a greater effect on instrument viscosity data within each temperature $\left(4,20\right.$, and $\left.50^{\circ} \mathrm{C}\right)$ than fat. Sensory perception of yellowness was not highly correlated with $b^{*}$ values. Multiple linear regressions of $\mathrm{L}$, a, and $\mathrm{b}^{*}$ values produced more robust predictions for both sensory whiteness and yellowness than simple linear regression with $\mathrm{L}$ and $\mathrm{b}^{*}$ values alone, and may be a useful instrumental approach for monitoring processing and quality control of sensory whiteness and yellowness of milk protein beverages.

\section{ACKNOWLEDGMENTS}

Use of names, names of ingredients, and identification of specific models of equipment is for scientific clarity and does not constitute any endorsement of product by authors, Cornell University, or the Northeast Dairy Foods Research Center. Funding provided in part by the National Dairy Council (Rosemont, IL) and the Northeast Dairy Foods Research Center (Cornell University, Ithaca, NY). The technical assistance of laboratory staff members Chassidy Coon, Michelle Bilotta, and Sara Hatch from the Department of Food Science at Cornell University (Ithaca, NY) with analytical testing was greatly appreciated.

\section{REFERENCES}

Adams, M. C., E. E. Hurt, and D. M. Barbano. 2015. Effect of ceramic membrane channel geometry and uniform transmembrane pressure on limiting flux and serum protein removal during skim milk microfiltration. J. Dairy Sci. 98:7527-7543. https://doi.org/10.3168/ jds.2015-9753.

Cheng, N., D. M. Barbano, and M. A. Drake. 2018. Hunter versus CIE color measurement systems for analysis of milk based beverages. J. Dairy Sci. 101:4891-4905.

CIE (International Commission on Illumination). 1978. Recommendations on uniform color spaces, color-difference equation, psychometric color terms, Supplement No. 2 to CIE Publication No. 15. Bureau Central de la CIE.

Croissant, A. E., S. P. Washburn, L. L. Dean, and M. A. Drake. 2007. Chemical properties and consumer perception of fluid milk from conventional and pasture-based production systems. J. Dairy Sci. 90:4942-4953.

Drake, M. A., Y. Karagul-Yuceer, K. R. Cadwallader, G. V. Civille, and P. S. Tong. 2003. Determination of the sensory attributes of dried milk powders and dairy ingredients. J. Sens. Stud. 3:199-213.

Glantz, S. A., and B. K. Slinker. 2001. Multicollinearity and what to do about it. Pages 185-187 in Primer of Applied Regression \& Analysis of Variance. 2nd ed. McGraw-Hill Inc., New York, NY.

Guinard, J. X., and R. Mazzucchelli. 1999. Effects of sugar and fat on the sensory properties of milk chocolate: descriptive analysis and instrumental measurements. J. Sci. Food Agric. 79:1331-1339.

Hetherington, M. J., and D. B. MacDougall. 1991. Visual and instrumental attribute models of fruit juices and milk. Food Qual. Prefer. 3:165-174.

Holt, C. 1975. Casein micelle size from elastic and quasi-elastic light scattering measurements. Biochim. Biophys. Acta 400:293-301.

Hunter, R. S., and R. W. Harold. 1987. Uniform Color Scale. Chapter 8 in The Measurement of Appearance. 2nd ed. John Wiley and Sons Inc., New York, NY.

Hunter Associates Laboratory. 2012. Measuring Color using Hunter L a, b versus CIE 1976 L*a*b*. Application Note. 1005.00. Accessed Oct. 12, 2017. https://www.hunterlab.com/de/an-1005-de.pdf.

Johnson, A. H. 1974. The composition of milk. Pages 1-57 in Fundamentals of Dairy Chemistry. 2nd ed. B. H. Webb, A. H. Johnson, and J. A. Alford, ed. The AVI Publishing Company Inc., Westport, CT.

Lee, A. P., D. M. Barbano, and M. A. Drake. 2017. The influence of ultra-pasteurization by indirect heating versus direct steam injection on skim and 2\% fat milks. J. Dairy Sci. 100:1688-1701.

McCarthy, K. S., K. Lopetcharat, and M. A. Drake. 2017. Milk fat threshold determination and the effect of milk fat content on consumer preference for fluid milk. J. Dairy Sci. 100:1702-1711.

Meilgaard, M., G. V. Civille, and B. T. Carr. 2007. Descriptive analysis techniques. Chapter 10 in Sensory Evaluation Techniques, 4th ed. CRC Press, Boca Raton, FL. 
Misawa, N., D. M. Barbano, and M. A. Drake. 2016. Influence of casein as a percentage of true protein and protein level on color and texture of milks containing 1 and 2\% fat. J. Dairy Sci. 99:5284-5304.

Pangborn, R. M., K. E. Bos, and J. S. Stern. 1985. Dietary fat intake and taste responses to fat in milk by under, normal, and overweight women. Appetite 6:25-40.

Phillips, L. G., and D. M. Barbano. 1997. The influence of fat substitutes based on protein and titanium dioxide on the sensory properties of lowfat milks. J. Dairy Sci. 80:2726-2731.

Phillips, L. G., M. L. McGiff, D. M. Barbano, and H. T. Lawless. 1995a. The influence of fat on the sensory properties, viscosity and color of low-fat milks. J. Dairy Sci. 78:1258-1266.

Phillips, L. G., M. L. McGiff, D. M. Barbano, and H. T. Lawless. 1995b. The influence of nonfat dry milk on the sensory properties, viscosity and color of lowfat milks. J. Dairy Sci. 78:2113.

Quiñones, H. J., D. M. Barbano, and L. G. Phillips. 1997. Influence of protein standardization by ultrafiltration on the viscosity, col- or, and sensory properties of skim and $1 \%$ milk. J. Dairy Sci. 80:3142-3151.

Quiñones, H. J., D. M. Barbano, and L. G. Phillips. 1998. Influence of protein standardization by ultrafiltration on the viscosity, color, and sensory properties of 2 and 3.3\% milks. J. Dairy Sci. 81:884894.

Tárrega, A., and E. Costell. 2007. Colour and consistency of semi-solid dairy desserts: Instrumental and sensory measurements. J. Food Eng. 78:655-661.

Walstra, P. 1965. Light scattering by milk fat globules. Neth. Milk Dairy J. 19:93.

Zulewska, J., and D. M. Barbano. 2014. The impact of linear velocity and flux on performance of ceramic graded permeability membranes when processing skim milk at $50^{\circ}$ C. J. Dairy Sci. 97:26192632 . 